\title{
Laboratory Tests of A Residential Unitary Water-Source Heat Pump
}

U.S. DEPARTMENT OF COMMERCE National Bureau of Standards National Engineering Laboratory Center for Building Technology Building Equipment Division

Washington, DC 20234

November 1982

Sponsored by:

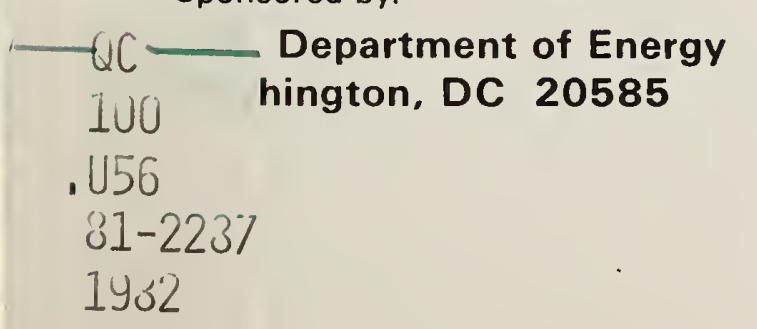



William J. Mulroy

George E. Kelly

U.S. DEPARTMENT OF COMMERCE

National Bureau of Standards

National Engineering Laboratory

Center for Building Technology

Building Equipment Division

Washington, DC 20234

November 1982

Sponsored by:

U.S. Department of Energy

Washington, DC 20585

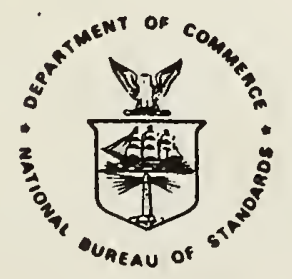

U.S. DEPARTMENT OF COMMERCE, Malcolm Baldrige, Secretary NATIONAL BUREAU OF STANDARDS, Ernest Ambler, Director 
LABORATORY TESTS OF A RESIDENTIAL UNITARY WATER-SOURCE HEAT PUMP

William J. Mulroy

George E. Kelly

U.S. DEPARTMENT OF COMMERCE

National Bureau of Standards

National Engineering Laboratory

Center for Building Technology

Building Equipment Division

Washington, DC 20234

November 1982

Sponsored by:

U.S. Department of Energy

Washington, DC 20585

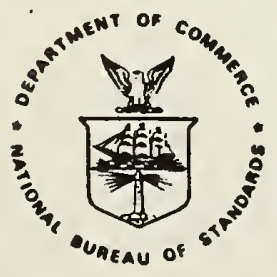

U.S. DEPARTMENT OF COMMERCE, Malcolm Baldrige, Secretary NATIONAL BUREAU OF STANDARDS, Ernest Ambler, Director 

Abstract

The performance of a residential heat pump was measured in the laboxatory over a broad range of source water temperatures $\left(40^{\circ} \mathrm{F}\right.$ to $\left.90^{\circ} \mathrm{F}\right)$. Tests were parformed in both heating and cooling operational modes and for both steady-state and cyclic operation.

For both heating and cooling operation, the unit capacity and COP were found to be linear functions of the average of the unit source and outlet water temperatures. In heating, the unit capacity, COP, and part load performance increased with increasing water temperature. In cooling, the unit capacity, COP, and part load performance decreased with increasing water temperature. The measured part load degradation coefficients ranged from 0.09 to 0.21 for heating and from 0.10 to 0.18 for cooling. An appendix is included in which the effect of the degradation coefficient and of supplemental resistance heat on the unit heating and cooling seasonal performance factors is calculated.

Key Words: Central heating equipment; cooling; heat pumps; heating; heating seasonal performance; heating seasonal periormance factor; test method; water source heat pumps. 
Abstract . . . . . . . . . . . . . . . . . . . . 111

List of Figures . . . . . . . . . . . . . . . . . v v

Llst of Tables ......................... . . vi

SI Conversion Factors ....................... . vil

1. INTRODUCTION . . . . . . . . . . . . . . . . . 1

2. DESCRIPTION OF TEST SPECIMEN . . . . . . . . . . . . . . 2

3. DESCRIPTION OF TEST APPARATUS . . . . . . . . . . . . . 3

4. TEST PROCEDURE . . . . . . . . . . . . . . . . . 5

5. STEADY-STATE TEST RESULTS . . . . . . . . . . . . . 8

5.1 Steady-State HeatIng Test Results . . . . . . . . . 8

5.2 Steady-State Cooling Test Results . . . . . . . . . . . 8

6. CYCLIC TEST RESULTS . . . . . . . . . . . . . . . 9

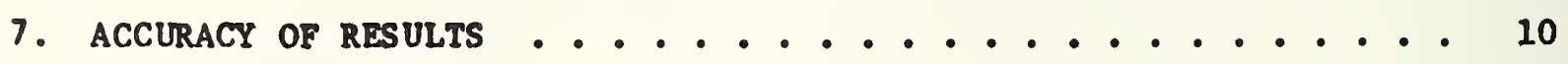

8. DISCUSSION AND CONCLUSIONS . . . . . . . . . . . . . . . 12

9. REPERENCES . . . . . . . . . . . . . . . . . . 14 APPENDIX A - SEASONAL PERFORMANCE CALCULATIONS . . . . . . . . . . 


\section{List of Figures}

$\underline{\text { Page }}$

Figure 1. Heat pump installed in test apparatus 15

Figure 2. Heat pump installed in test apparatus 16

$\begin{array}{ll}\text { Figure 3. Air flow measurement tunnel } & 17\end{array}$

Figure 4. Variation of heating capacity with entering water 20 temperature for different inlet-to-outlet water temperature differentials

Figure 5. Variation of heating capacity with mean water temperature 21

Figure 6. Variation of heating COP with mean water temperature 22

Figure 7. Variation of cooling capacity with mean water temperature 25

Figure 8. Variation of cooling COP with mean water temperature 26

Figure 9. High temperature heating cyclic tests 27

Figure 10. Low temperature heating cyclic tests 28

Figure 11. High temperature cooling cyclic tests 29

Figure 12. Low temperature cooling cyclic tests 30

Figure 13. Linear regression fit to data on degradation of the 31 coefficient of performance at part-load operation

Figure 14. Variation of coefficient of degradation with mean water 32 temperature 
Table 1. Steady-State Heating Test Results

Table 2. Steady-S tate Heating Test Conditions

Table 3. Steady-State Cooling Test Results

Table 4. Steady-S tate Cooling Test Conditions

Table Al. Design Conditions and Calculated Unit Performance for Selected Cities

Table A2. Comparison of Seasonal Performance Factors to SteadyState Coefficients of Performance for the Unit Sized at the Minimum Design Heating and Cooling Loads

Table A3. Comparison of Cooling Seasonal Performance Factor to Steady-State Coefficients of Performance for the Unit Sized at the Maximum Design Cooling Loads

Table A4. Comparison of Heating Seasonal Performance Factors to Steady-State Coefficients of Performance for the Unit Sized at the Maximum Design Heating Load

Table A5, Sample Bin Method Calculation, Region IV, Maximum 
SI Conversion Factors

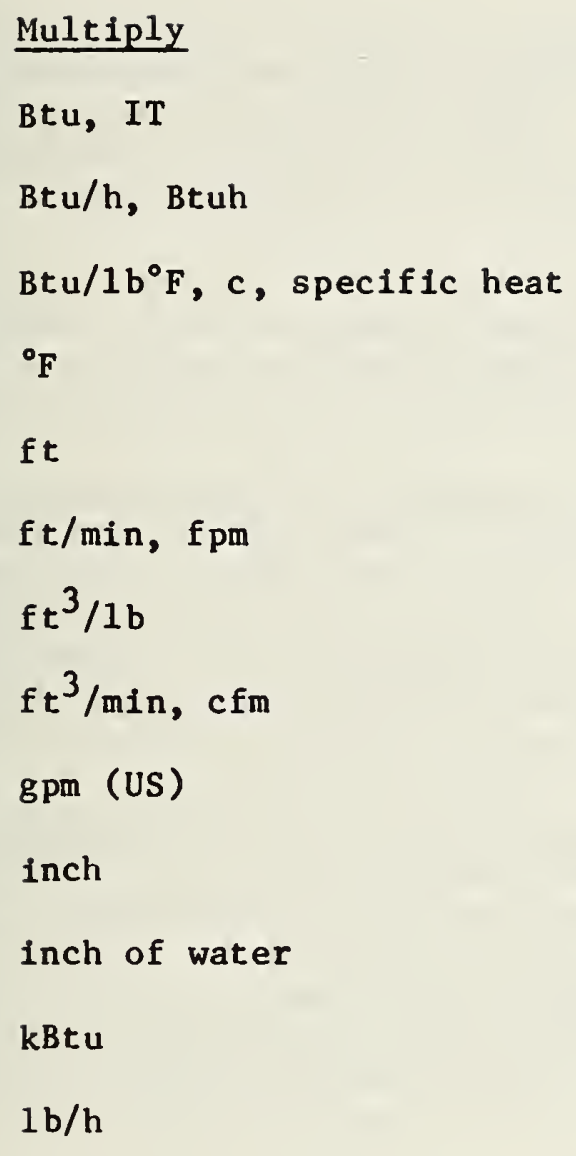

$\begin{array}{ll}\begin{array}{ll}\text { By } \\ 1.055\end{array} & \text { To Obtain } \\ 0.293 & \mathrm{~kJ} \\ 4.19 & \mathrm{~W} \\ { }^{\circ} \mathrm{C}=\left({ }^{\circ} \mathrm{F}-32\right) / 1.8 \\ 0.3048 & \mathrm{~m} / \mathrm{kg}^{\circ} \mathrm{C} \\ 0.00508 & \mathrm{~m} / \mathrm{s} \\ 0.0623 & \mathrm{~m} / \mathrm{kg} \\ 0.472 & 1 / \mathrm{s} \\ 0.0631 & 1 / \mathrm{s} \\ 25.4 & \mathrm{~mm} \\ 3.38 & \mathrm{kPa} \\ 1055 & \mathrm{~kJ} \\ 0.126 & \mathrm{~g} / \mathrm{s}\end{array}$





\section{INTRODUCTION}

Traditionally, residential water-source unitary heat pumps have been applied primarily in those areas of the Southeastern United States which have abundant, high temperature ground water. This was reflected in ARI Standard 320-76, which specified a temperature of $70^{\circ} \mathrm{F}\left(21.1^{\circ} \mathrm{C}\right)$ for water entering the refrigerant-towater heat exchanger as the heating rating point.

In the search for more efficient methods of residential heating, it has become apparent that the water-source heat pump could provide significant energy savings. Some of the new applications that expand the use of this device beyond its traditional role and require new methods of rating are:

1) Heating with low temperature ground water - Although water-source heat pumps have traditionally been employed in areas of the country where the ground water is comparatively warm, when they are designed to operate on relatively cold (down to $40^{\circ} \mathrm{F}\left(4.4^{\circ} \mathrm{C}\right.$ )) ground water their geographic range of application can be expanded considerably. With proper design, a ground-watersource heat pump should operate with a higher seasonal efficiency than an air-to-air heat pump in the same climate.

2) Solar-assisted heat pump operation - In order to transfer heat ef fectively, the fluid temperature of a solar collector should be approximately $30^{\circ} \mathrm{F}\left(-1.1^{\circ} \mathrm{C}\right)$ warmer than the indoor air temperature of the home which it is heating. Under this condition, a solar collector would be ineffective when its fluid temperature dropped below $100^{\circ} \mathrm{F}\left(70^{\circ} \mathrm{F}+30^{\circ} \mathrm{F}\right)$. Solar heated fluid at temperatures below $100^{\circ} \mathrm{F}\left(37.8^{\circ} \mathrm{C}\right)$, although unsuitable for direct heat transfer space heating would, however, be a suitable source of energy for a water-source heat pump.

3) Intrastructure heat transfer - Frequently large commercial structures have interior zones which require year-round cooling due to high internal loads (e.g. lights, people, computers, equipment, etc.). A water-to-air heat pump is ideal for this application because the energy extracted in the process of cooling the interior zones can be used to heat exterior zones during the heating season. Similar residential applications may be possible.

The primary purpose of the tests reported herein is to provide sufficient data on the performance of a typical residential unitary water-source heat pump to enable development of new test and rating methods. These methods should provide sufficient information on water-source heat pump performance and cost of operation so that consumers can purchase cost-effective energy conserving heat-pump systems. It is important in the creation of test and rating methods to develop procedures to measure part-load performance. Including part load performance in calculation of heat pump system seasonal energy usage allows credit to be given to innovations in heat pump design and control which improve part load as well as full load, steady-state efficiency. 


\section{DESCRIPTION OF TEST SPECIMEN}

The heat pump tested was of commercially avallable unitary design with an air handling compartment above another compartment containing the compressor and the water-to-refrigerant heat exchanger. The two compartments were separated by an insulated panel. The manufacturer's rated heating and cooling capacities for the unit were $72,000 \mathrm{Btuh}(21.1 \mathrm{kw})$ and $60,000 \mathrm{Btuh}(17.6 \mathrm{kw})$, respectively.

The air handling system was rated to deliver $2200 \mathrm{cfm}\left(1.04 \mathrm{~m}^{3} / 5\right)$ at 0.15 inches of water $(37 \mathrm{~Pa})$ external static pressure. The blower was belt-driven by a $3 / 4$ horse-power (560W) motor equipped with an adjustable pulley. Included in the air handling system were automatically controlled dampers designed to restrict air flow and increase refrigerant head pressure during low temperature startup in the heating mode. Manual control was substituted for automatic control of these dampers for the tests discussed in this report.

Refrigerant flow in both heating and cooling modes was controlled by automatic expansion valves. The use of automatic (instead of thermostatic) expansion valves made adjustment necessary between tests. The expansion valves were manually adjusted to provide a nominal $15^{\circ} \mathrm{F}\left(8.3^{\circ} \mathrm{C}\right)$ of superheat for all tests. The refrigerant charge recommended by the manufacturer was 14 pounds $(6.4 \mathrm{~kg})$ of refrigerant 22. The unit was tested as charged by the manufacturer.

The water-to-refrigerant heat exchanger was of co-axial tube-in-tube design. Included in the water circuit were valves designed to modulate water flow to maintain constant refrigerant conditions in the heat exchanger during both heating and cooling mode operation. These valves were completely opened for the test series described herein and the water flow was controlled manually. The heat exchanger was not equipped with a water-circulating pump and, in these laboratory tests, water supply line pressure was used to move water through the water-to-refigerant heat exchanger.

The heat pump was equipped with a separate refrigerant-to-water heat exchanger on the compressor discharge for the purpose of supplying domestic hot water. This heat exchanger was disabled by draining and disconnecting its integral pump prior to the start of the test series. 


\section{DESCRIPTION OF TEST APPARATUS}

The test apparatus was built in conformance with ASHRAE Standard 37-78 using the Air-Enthalpy Method, Indoor Side, as the primary test method, and the Outdoor Water Coil Method as the secondary test method. The unit with the test duct installed is shown in figures 1,2 and 3 .

Air flow rates were determined by measuring the pressure drop across a 10-inch $(254 \mathrm{~mm})$ diameter nozzle. The pressure drop across the nozzle was measured using four interconnected upstream pressure taps at the nozzle entrance and four downstream taps at the exit which were centered laterally on each side of the air flow measurement tunnel. The upstream pressure taps were located approximately 9 inches $(203 \mathrm{~mm})$ before the nozzle inlet and the downstream taps were set even with the nozzle outlet. A pitot tube was installed, as a check, centered 1 inch $(25 \mathrm{~mm})$ above the nozzle outlet. Figure 3 is a schematic of the air flow measuring apparatus.

Average air temperatures entering and leaving the unit and at the nozzle entrance were measured using two sets of 16 thermocouples connected in parallel. The temperature difference between the air entering the unit and the air entering the nozzle was measured by a 32-junction (16 junctions on each side) thermopile. An additional 32-junction thermopile was used to measure the difference between the air temperatures entering and leaving the unit.

Wet-bulb temperatures of air entering the unit and the nozzle were measured by single thermocouples covered with wetted wicks. Single dry-bulb thermocouples near the wet-bulb thermocouples were used to allow calculation of humidity.

The water flow rate was measured by a turbine-type flowmeter. A second turbine flowmeter was installed in series as a backup but was not used. In addition to measuring flow rates, an integrating recorder was used to measure integrated water flow.

The inlet and outlet water temperatures were measured by single thermocouples in wells installed at the unit inlet and outlet fittings. Two 32-junction thermopiles were installed in these same wells to measure the water inlet-to-outlet temperature difference.

Thermocouples were attached to the unit refrigerant lines entering and leaving the water-to-refrigerant and air-to-refrigerant heat exchangers.

Pressure gages were installed to measure the suction and discharge pressures at the compressor.

The unit's total power and fan power were each recorded separately from watt-hour meters having a 10 watt-hour resolution.

Temperature and millivolt signals were recorded by an automatic data acquisition system having the capability of a programmable time interval between data scans. 
During the cyclic tests, an electronic integrator was used to record the air-side thermopile signal for the period between compressor-on and

compressor-off. Identical instrumentation was used for recording the signal from the water-side thermopile.

Condensate was collected for all cooling tests. The amount of condensate collected was measured by weighing on a balance which had a resolution of 0.02 pounds $(0.01 \mathrm{~kg})$. For the steady-state tests, condensate collection was begun at the beginning of the data period and terminated at its end. In the cyclic tests, the condensate collection was allowed to continue 3 to 10 minutes after shutdown to insure complete drainage from the coil. The collected condensate was used to calculate the latent portion of the total cooling capacity. Air flow, integrated water flow, barometric pressure, suction and discharge pressures, power consumption, and condensate collection data were taken manually.

During all tests, crucial temperature and millivolt values were continuously monitored by a 24-point printing recorder in addition to the data acquisition system.

A range of inlet water temperatures from $40^{\circ} \mathrm{F}\left(4.4^{\circ} \mathrm{C}\right)$ to $90^{\circ} \mathrm{F}\left(32.2^{\circ} \mathrm{C}\right)$ was provided by tapping into chilled water or service water lines in the building where tests were conducted and mixing the water from the lines.

Dry-bulb and wet-bulb air temperatures entering the unit were controlled by the test room air conditioning equipment. In order to maintain conditions additional heat and humidity were required, and were supplied by a gas furnace and by portable room humidifiers.

The unit air flow rate ranged from $1960\left(0.92 \mathrm{~m}^{3} / \mathrm{s}\right)$ to $2060{ }_{3}\left(0.97 \mathrm{~m}^{3} / \mathrm{s}\right)$ standard cfm during steady-state heating tests and from $2085(0.98 \mathrm{~m} / \mathrm{s})$ to $2100\left(0.99 \mathrm{~m}^{3} / \mathrm{s}\right)$ standard cfm during steady-state cooling tests. The air flow was not manually adjusted between tests, but allowed to vary as a function of air density. The minimum and maximum steady-state air flow rates recorded resulted in air velocities through the 10 -inch nozzle of $3770 \mathrm{fpm}(19.2 \mathrm{~m} / \mathrm{s})$ and $4020 \mathrm{fpm}(20.4 \mathrm{~m} / \mathrm{s})$, respectively. The above velocities are within the range of 3000 to $7000 \mathrm{fpm}$ $(15.2$ to $35.6 \mathrm{~m} / \mathrm{s}$ ) specified by ASHRAE Standard 37-78. 
For steady-state tests, the unit was allowed to run for 1 hour at steady conditions prior to taking data. Data were recorded fin 10 minute intervals for a period of 1 hour. For all tests the refrigerant expansion valve of the unit was set to produce approximately $15^{\circ} \mathrm{F}\left(8.3^{\circ} \mathrm{C}\right)$ of superheat in the refrigerant vapor leaving the evaporator.

Cyclic tests were performed at two sets of cycling rates.

These thermostat cycling rate sets were calculated by rounding values calculated from the equation:

$$
\mathrm{C}=4 \mathrm{NX}(1-\mathrm{X})
$$

where $\mathrm{C}=$ the cycling rate in cycles per hour.

$\mathrm{N}=$ the cycling rate at $50 \%$ on-time and was set equal to either 2 or 5 for this study.

$\mathrm{X}=$ fractional on-time of the unit.

As an example, for the fast set of cycling times employed in this study, it was assumed that the unit would cycle five times per hour at 50 percent ontime. Substituting an on-time of 20 percent in the above equation results in $C=4 \times 5 \times 0.2(0.8)=3.2$ cycles per hour or $60 / 3.2=18.8$ minutes per cycle with an on-time of $0.2 \times 18.8=3.8$ minutes. This value ( 3.8 minutes) was rounded to 4 minutes to simplify performance of the cyclic test. The other cycling times for the fast cycling rate set employed to determine the maximum cycling effect were 4 minutes on/15 minutes off, six on/six off and 15 on/four off.

A somewhat slower set of cyclic rates, corresponding to two cycles/hour at 50 percent on-time, consisting of nine on/38 off, 15 on/15 off, 38 on/nine off, was used to find the system performance under what was felt to be more normal cycling conditions.

The data acquisition system was used to record data at intervals of one to three minutes during cyclic testing, depending on cycle length.

During cyclic tests, air flow rate and unit suction and discharge pressure measurements were read once during each on-period and were used with the temperatures existing at the time the reading was taken to determine the air flow rate and refrigerant superheat. These measurements were recorded approximately at the midpoint of the on-period.

For cyclic tests, integrated quantities (watthours, water flow, thermopile millivolts, time) were read when the compressor started or stopped.

For cyclic tests, the air dampers on the unit were shut during the off-period to reduce heat transfer by convection. Off-period convection flow was felt to be an installation characteristic as opposed to a unit characteristic.

Water was prevented from circulating through the unit during the off-period of the cyclic tests by diverting the flow through a bypass to maintain a constant water temperature. 
In addition to the steady-state and cyclic operating tests, a heat loss test was performed to measure the thermal loss factor of the compressor compartment. This heat loss test was performed by heating the compartment to a steady-state temperature with a fixed electric resistance heater and dividing the heater power input by the resulting steady-state compartment temperature less the room air temperature. This loss factor, in conjunction with compartment interior and ambient temperatures, was used to determine the unit jacket loss from this compartment. Determining the jacket losses allowed a more accurate comparison of results calculated using the air-side and water-side measured data.

The air side heating capacity during a test was calculated from the equation:

$$
q_{t h i}=\frac{60 \times Q_{m_{i}} \times C_{p a} \times\left(t_{a 2}-t_{a 1}\right)}{v_{n}^{\prime}\left(1+w_{n}\right)},
$$

the air side cooling capacity was calculated from the equation:

$$
\begin{aligned}
& q_{t c i}=q_{s c i}+q_{1 c i} \\
& q_{s c i}=\frac{60 \times Q_{m_{i}} \times c_{p a} \times\left(t_{a 1}-t_{a 2}\right)}{v_{n}^{\prime} \times\left(1+w_{n}\right)}, \\
& q_{1 c i}=1060 w_{c}
\end{aligned}
$$

the water side heating capacity was calculated from the equation:

$$
q_{\text {tho }}=w_{w} C_{p w}\left(t_{w 3}-t_{w 4}\right)+3.413 E_{t}-U A_{c c}\left(t_{c c}-t_{a}\right) \text {, }
$$

and the water side cooling capacity was calculated by the equation:

$$
q_{t c o}=w_{w} C_{p w}\left(t_{w 4}-t_{w 3}\right)-3.413 E_{t}+U A_{c c}\left(t_{c c}-t_{a}\right) .
$$

In the above equations, the following nomenclature has been employed:

$$
\begin{aligned}
& \mathrm{C}_{\mathrm{pa}}=\text { specific heat of air, Btu per }(1 \mathrm{~b})\left({ }^{\circ} \mathrm{F}\right) \text { of dry air } \\
& \mathrm{C}_{\mathrm{pw}}=\text { specific heat of water, Btu per }(1 \mathrm{~b})\left({ }^{\circ} \mathrm{F}\right) \\
& \mathrm{E}_{\mathrm{t}} \quad=\text { power input, total watts } \\
& \mathrm{Q}_{\mathrm{mi}}=\text { air flow, indoor, measured, cfm } \\
& \mathrm{q}_{1 \mathrm{ci}}=\text { latent cooling capacity, (indoor side data), Btuh }
\end{aligned}
$$




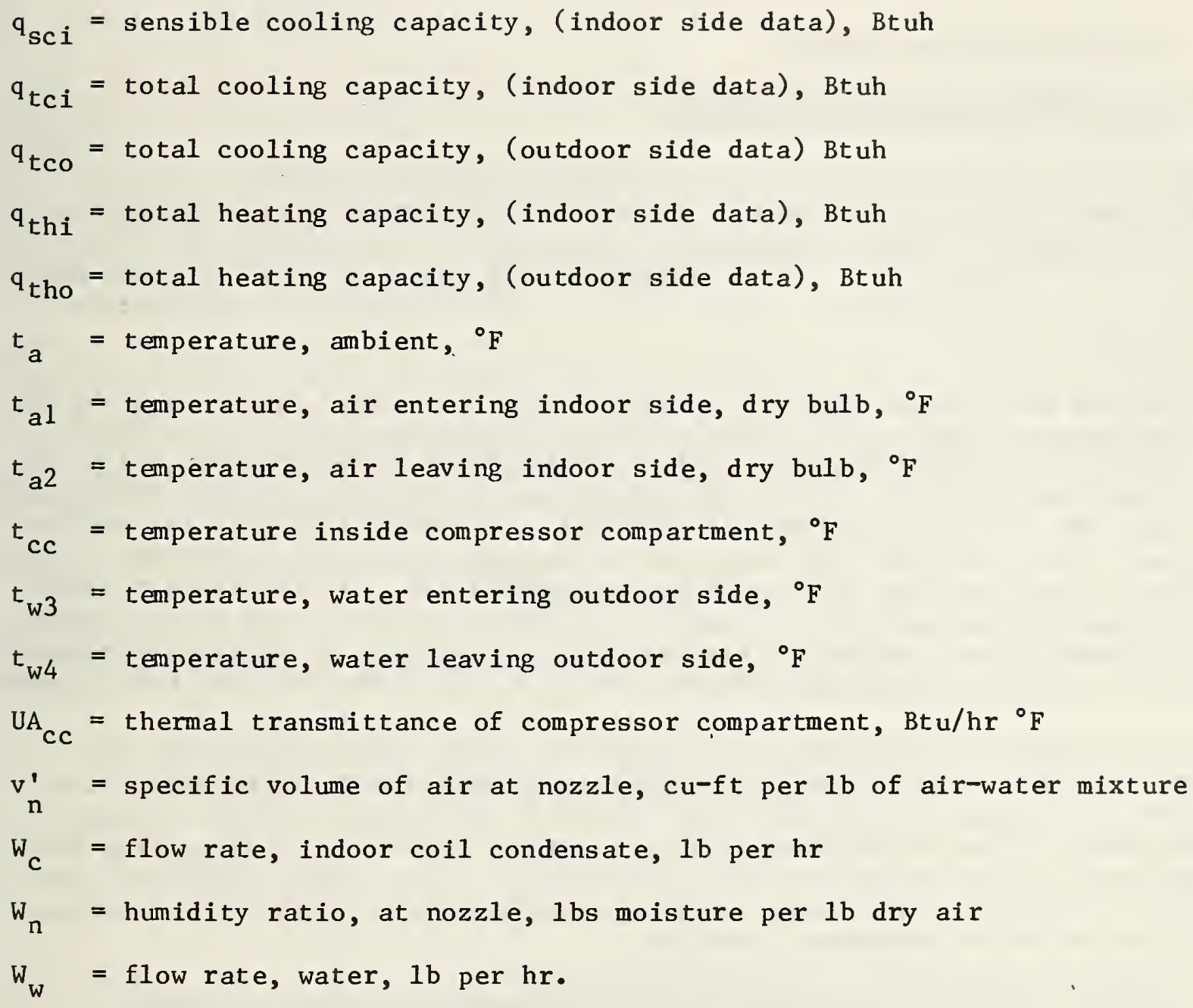




\section{STEADY-STATE TEST RESULTS}

\subsection{STEADY-STATE HEATING TEST RESULTS}

The steady-state tests were run at conditions chosen to generate a set of heating capacity and COP curves as a function of entering water temperature for inlet-to-outlet water temperature differences of $10^{\circ} \mathrm{F}, 15^{\circ} \mathrm{F}$ and $20^{\circ} \mathrm{F}$ $\left(5.6^{\circ} \mathrm{C}, 8.3^{\circ} \mathrm{C}\right.$ and $\left.11.1^{\circ} \mathrm{C}\right)$. For the steady-state tests, the entering air temperature was held constant at $70^{\circ} \mathrm{F}\left(21.1^{\circ} \mathrm{C}\right)$ and the evaporator superheat at $15^{\circ} \mathrm{F}\left(8.3^{\circ} \mathrm{C}\right)$.

The results and test conditions for these tests are listed in tables 1 and 2 . The temperature limit on the range of water temperatures used in the tests was set by ice formation in the water-to-refrigerant heat exchanger which occurred when the leaving water temperature was below approximately $35^{\circ} \mathrm{F}\left(1.7^{\circ} \mathrm{C}\right)$. Although the unit was provided with reverse cycle defrosting this feature was not used since its operation would not have produced results comparable to the results of the tests at the higher water temperatures. At the highest inlet water temperatures used in this test series $\left(90^{\circ} \mathrm{F}, 32.2^{\circ} \mathrm{C}\right)$, the unit capacity was limited by the size of the expansion valve, since at or above this temperature the evaporator superheat exceeded $15^{\circ} \mathrm{F}\left(8.3^{\circ} \mathrm{C}\right)$ with the valve fully opener.

The three curves of capacity as a function of inlet water temperature are shown in figure 4. In figure 5, the same capacity variation data are plotted against the average of the inlet and outlet water temperatures (mean water temperature). Use of the mean water temperature instead of the entering water temperature as the independent variable results in the three inlet-to-outlet temperature differential curves becoming superimposed, eliminating temperature differential as an independent variable.

In figure 6, the heating coefficient of performance may also be observed to be a linear function of mean water temperature.

\subsection{STEADY-STATE COOLING TESTS}

Steady-state cooling tests were performed with a range of inlet water temperatures from $42^{\circ} \mathrm{F}$ to $95^{\circ} \mathrm{F}\left(5.6^{\circ} \mathrm{C}\right.$ to $\left.35.0^{\circ} \mathrm{C}\right)$ and a range of inlet-to-outlet temperatures differentials from $10^{\circ} \mathrm{F}$ to $40^{\circ} \mathrm{F}\left(5.6^{\circ} \mathrm{C}\right.$ to $\left.22.2^{\circ} \mathrm{C}\right)$.

The data and results for these tests are summarized in tables 3 and 4 and figures 7 and 8 .

Although data were taken that would allow plotting of capacity and COP as functions of temperature differential at different entering water temperatures, it was found that these cooling data fell along a single line when plotted against mean water temperature, as had the heating data. Thus the results in figures 7 and 8 are shown as a function of the mean water temperature. 


\section{CYCLIC TEST RESULTS}

Cyclic tests were performed at high and low entering water temperatures in both heating and cooling modes.

Cyclic test results are shown in figures 9 through 14. Each data point plotted is the mean of the values measured during two to four individual on/off cycles. The dashed lines show one standard deviation away from this plotted mean. All reported values are based upon air side data.

The percent full load COP is defined as the ratio of the COP when cycling to the steady-state COP at the same ambient conditions. The heating (cooling) load is defined as the ratio of the cyclic heating (cooling) done over a complete onoff cycle to the steady-state heating (cooling) that would have been done if the unit had remained on over the entire cycle which makes $L$ a percent rather than a "load". This may be expressed in algebraic form as follows:

$$
L=\frac{Q c y c}{Q s s(\text { ton }+ \text { toff })}
$$

where L=heating or cooling load

$$
\begin{aligned}
& \text { Qcyc=heating (cooling) done over a cycle } \\
& \text { Qss=steady-state heating (cooling) capacity } \\
& \text { ton=on-time } \\
& \text { tof } f=\text { of } f \text {-time }
\end{aligned}
$$

The degradation coefficient, defined as the slope of a line drawn through the 20 percent and 100 percent load points of the part-load coefficient of performance degradation curve (see references 1 and 2 ), is tabulated below:

Mean Water Temp.l

Heating or Cooling Test

\author{
Degradation Coefficient \\ High Cycling Rate Low Cycling Rate \\ (5 cph at 50\% load) (2 cph at 50\% load)
}
$95.7^{\circ} \mathrm{F}\left(35.4^{\circ} \mathrm{C}\right)$ Water $/$ Cooling
0.189
0.163
$44.7^{\circ} \mathrm{F}\left(7.1^{\circ} \mathrm{C}\right)$ Water/Heating
0.200
0.135
$54.2^{\circ} \mathrm{F}\left(12.3^{\circ} \mathrm{C}\right)$ Water Cooling
0.112
0.105
$85.5^{\circ} \mathrm{F}\left(29.7^{\circ} \mathrm{C}\right)$ Water/Heating
0.101
0.084

These degradation coefficients were calculated by performing a linear regression to the data plotted on a graph of percent full load Cop versus load. The resulting curve was then used to find the percent $\mathrm{full}$ load COP at 20 percent load. With this information, the degradation coefficient was determined from the following equation:

$$
C_{D}=\frac{100-\text { percent of full load COP at } 20 \% \text { load }}{80}
$$




\section{ACCURACY OF RESULTS}

In the heating mode, the average difference between the air and water side capacity measurments for the 10 steady-state tests was 1.8 percent, with the water side measurement, on the average, higher than the air side.

In the cooling mode the average difference between the air and water side capacity measurements for the 9 steady-state tests was 1.2 percent, again with the water side measurement higher, on average, than the air side.

Standard error and the coefficient of variation are given by the equations:

Standard Error $=\sqrt{\frac{\sum\left(y_{i}-y\right)^{2}}{n-2}}$

Coefficient of Variation $=\frac{\text { Standard Error }}{\bar{y}}$

Where $y_{i}=$ the $y$ value for the $i^{\text {th }}$ data point

$\mathrm{y}=$ the corresponding value from the least-squares fit

$\bar{y}=$ the average $\mathrm{y}$ value

$\mathrm{n}=$ the number of data points

The standard error between the heating capacity given by the linear regression fit to the capacity versus mean water temperature data and the individual data points is 2500 Btuh ( $732 \mathrm{~W})$, with the coefficient of variation being 3.8 percent. Similarly for the heating COP versus mean water temperature plot, the standard error is 0.0850 with a coefficient of variation of 2.8 percent.

For steady-state cooling the standard error between the capacity given by the linear regression fit to the capacity versus mean water temperature data and the individual data points of 1670 Btuh ( $489 \mathrm{~W})$, with the coefficient of variation being 3.4 percent. Similarly for the cooling COP versus mean water temperature plot, the standard error is 0.1048 with a coefficient of variation of 4.2 percent.

The standard deviation of the cyclic test data generally increased as the cycles became shorter and the run times less. The following table lists the maximum standard deviation as a percent of the mean observed at each cyclic rate for air side capacity and COP: 


\section{Cycling Times}

4 on $/ 15$ off

6 on $/ 6$ off

15 on $/ 4$ off

9 on $/ 38$ of $\mathrm{f}$

15 on $/ 15$ off

38 on $/ 9$ of $f$
Maximum Standard Deviation in Capacity, $\%$ of mean

2.2

1.0

0.4

1.1

0.8

0.4
Minimum Standard Deviation in COP, $\%$ of mean

2.8

2.0

1.1

2.0

1.6

1.5 


\section{DISCUSSION AND CONCLUSIONS}

For both heating and cooling, the capacity and COP of the heat pump under test could both be considered linear functions of the average (mean) temperature of the water in and out of the unit for inlet water temperatures ranging from $40^{\circ} \mathrm{F}$ to $90^{\circ} \mathrm{F}\left(4.4^{\circ} \mathrm{C}\right.$ to $\left.32.2^{\circ} \mathrm{C}\right)$.

The steady-state heating capacity and COP increased with increasing mean water temperature, as shown in figures 5 and 6 . A linear regression of the capacity and $C O P$ data versus mean water temperature was found to correlate the data wel1. The correlation indicates that, increasing the mean water temperature from $40^{\circ} \mathrm{F}$ to $80^{\circ} \mathrm{F}\left(4.4^{\circ} \mathrm{C}\right.$ to $\left.26.7^{\circ} \mathrm{C}\right)$ would result in the unit heating capacity increasing from $47,000 \mathrm{Btuh}(13.8 \mathrm{~kW})$ to $80,900 \mathrm{Btu} / \mathrm{h}(23.7 \mathrm{~kW})$. Similarly the COP would increase from 2.85 at a $40^{\circ} \mathrm{F}\left(4.4^{\circ} \mathrm{C}\right)$ mean water temperature to 3.25 at an $80^{\circ} \mathrm{F}\left(26.7^{\circ} \mathrm{C}\right)$ mean water temperature.

For the steady-state cooling data, a similar linear regression was made with the data correlating well. The results indicate that decreasing mean water temperature from $90^{\circ} \mathrm{F}\left(32.2^{\circ} \mathrm{C}\right)$ to $50^{\circ} \mathrm{F}\left(10^{\circ} \mathrm{C}\right)$ increases the capacity and COP from $46,900 \mathrm{Btu} / \mathrm{h}(13.7 \mathrm{~kW})$ and 2.3 to $57,500 \mathrm{Btu} / \mathrm{h}(16.8 \mathrm{~kW})$ and 3.24 respectively (see figures 6 and 7 ).

The coefficient of degradation of $\mathrm{COP}, \mathrm{C}_{\mathrm{D}}$, due to part-load operation was found to increase with decreasing mean water temperature in the heating mode and increase with increasing mean water temperature in the cooling mode. Assuming linearity and extrapolating the $C_{D}$ vs. mean water temperature data presented in figure 14 gives the following values for $C_{D}$ for heating cycle operation.

\begin{tabular}{lcc} 
& \multicolumn{2}{c}{ Heating Cycle $\mathrm{C}$} \\
\cline { 2 - 3 } Mean Water & $\begin{array}{l}5 \mathrm{cph} \text { at } \\
50 \% \text { load }\end{array}$ & $\begin{array}{r}2 \mathrm{cph} \text { at } \\
50 \% 1 \text { oad }\end{array}$ \\
Temperature & & 0.11 \\
$80^{\circ} \mathrm{F}\left(26.7^{\circ} \mathrm{C}\right)$ & 0.09 & 0.21 \\
$40^{\circ} \mathrm{F}\left(4.4^{\circ} \mathrm{C}\right)$ & 0.14 & $91 \%$ \\
$\quad$ increase & $56 \%$ &
\end{tabular}

Similarly the following $C_{D}$ values for cooling cycle operation may also be extrapolated from figure 14 :

\begin{tabular}{lcc} 
Mean Water & \multicolumn{2}{c}{ Cooling Cycle $\mathrm{C}_{p}$} \\
\cline { 2 - 3 } Temperature & $\begin{array}{l}50 \% \text { cph at } \\
20 \mathrm{cph} \text { at }\end{array}$ & $\begin{array}{l}50 \% \text { load } \\
50 \%\end{array}$ \\
\hline $50^{\circ} \mathrm{F}\left(10.0^{\circ} \mathrm{C}\right)$ & 0.10 & 0.10 \\
$90^{\circ} \mathrm{F}\left(32.2^{\circ} \mathrm{C}\right)$ & 0.18 & 0.16 \\
increase & $80 \%$ & $60 \%$
\end{tabular}


In an actual application the coefficient of degradation will have its greatest effect on seasonal power consumption when the unit is substantially oversized in comparison to the building heating or cooling load requirement. This will occur in the cooling mode when the unit is sized to meet the heating load in a climate where the summers are mild relative to the winters and the ratio of the cooling to the heating heat loss factor is at its maximum. Conversely, a large part load heating seasonal performance degradation will occur when the unit is sized to meet the cooling load in climate where the winters are mild relative to the summers and the ratio of the cooling to the heating heat loss factor is at its minimum.

To aid in evaluating the importance of the change in unit capacity, COP, and part-load performance degradation coefficient, $C_{D}$, with varying water temperatures, bin-method calculations of the seasonal performance factor were performed for a representative city in each of the six heating regions defined in [4].

The seasonal performance factor is the dimensionless ratio of the heating (cooling) done by unit over a heating (cooling) season to the total electrical energy used by the unit in the season. The heating (cooling) seasonal performance factor calculations include the effects of part-load performance through the part-load degradation factor.

These calculations of the seasonal performance factor for this heat pump when oversized by the maximum amount felt to be reasonable for heating (matched to minimum design heating load) and cooling (matched to minimum design heating load) are given in appendix A. For the minimum design heating loads, the calculated degradations in the heating seasonal performance factors due to part load operation shown in table A2 range from 12 percent to 13 percent for all six regions. The calculated degradation in the cooling seasonal performance factor, due to part load operation at the minimum cooling loads, also shown in table A2 range from eight percent to 10 percent for all six regions.

The minimum heating seasonal efficiency for this heat pump occurs when it is matched to its maximum design load and uses supplemental resistance heat to meet the building load at low outdoor temperatures. In the sample calculation of appendix A, the smallest heating seasonal performance factor occurred with the maximum cycling rate ( $5 \mathrm{cph}$ at 50 percent capacity) and when the unit was matched with the maximum design heating load ( 280 percent of the unit heating capacity) assumed for region IV (see Table A4). In this case the seasonal performance factor is 73 percent of the corresponding steady-state COP. The use of an undersized unit and consequently substantial amounts of supplemental resistance heat, while resulting in a significant seasonal efficiency loss, may be justified by the substantial reduction in first cost and by better load matching in the cooling season. 


\section{REFERENCES}

1. "Method of Testing, Rating and Estimating the Seasonal Performance of Central Air Conditioners and Heat Pumps Operating in the Cooling Mode" by George E. Kelly and Walter H. Parken, NBSIR 77-1271.

2. "Method of Testing, Rating and Estimating the Heating Seasonal Performance of Heat Pumps" by Walter H. Parken, George E. Kelly and David A. Didion, NBSIR 80-2002.

3. "Facility Design and Planning Engineering Weather Data" Departments of the Air Force, the Army, and the Navy, 1 July 1978, AFM 88-29, TM 5-785, NAVFAC P-89

4. "Proposed Rulemaking and Public Hearing Regarding Test Procedures for Central Air Conditioners, Including Heat Pumps." Office of Energy Conservation and Solar Applications, Department of Energy, Federal Register, Thursday, Apri1 19, 1979, part II, pages $23468^{\circ}$ to 23506 .

5. "Methods of Testing for Rating Unitary Air Conditioning and Heat Pump Equipment." ANSI/ASHRAE 37-1978.

6. "Standard for Water Source Heat Pumps." ARI 320-76. 

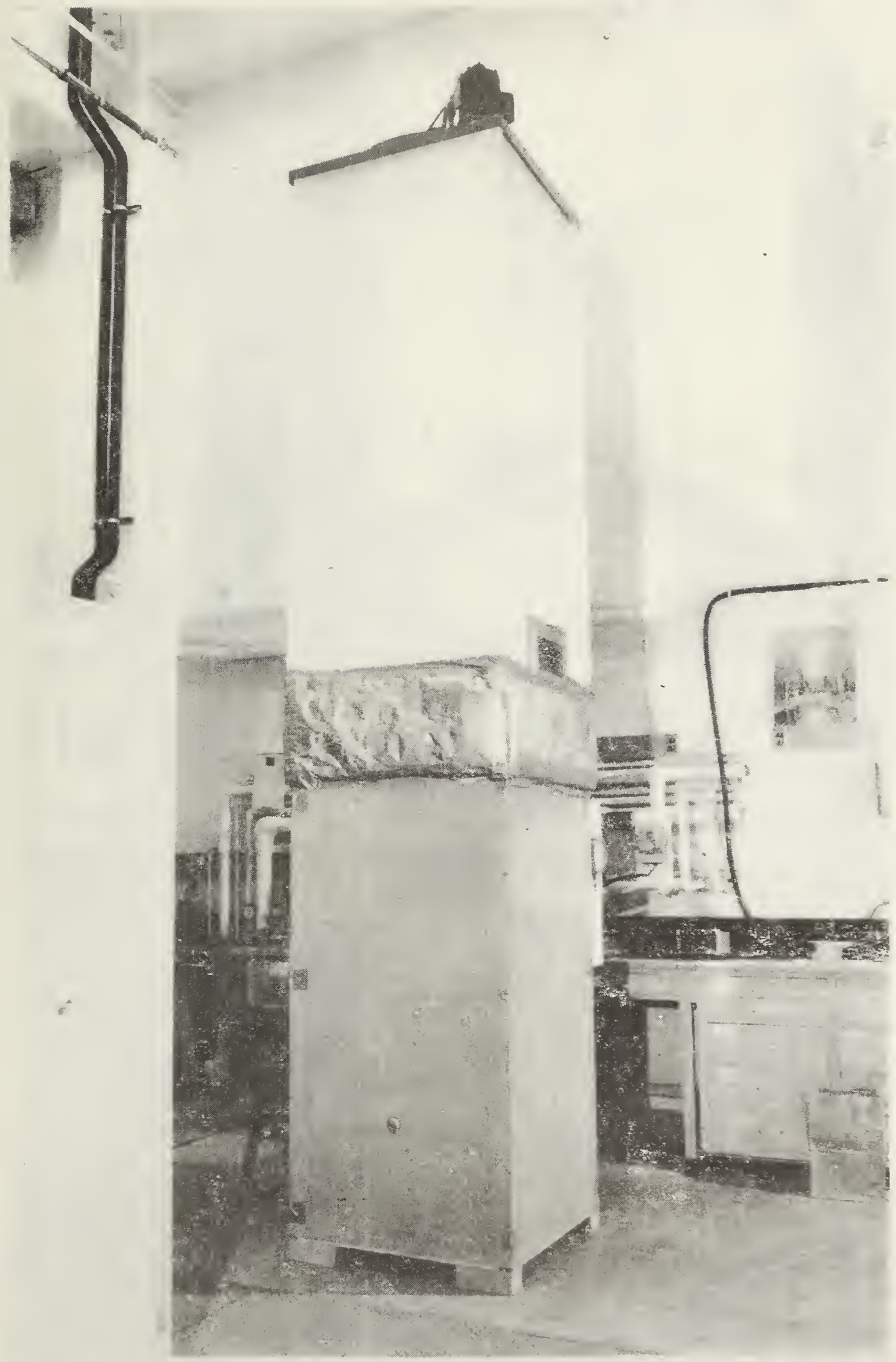

Figure 1. Heat Pump Installed in Test Apparatus 


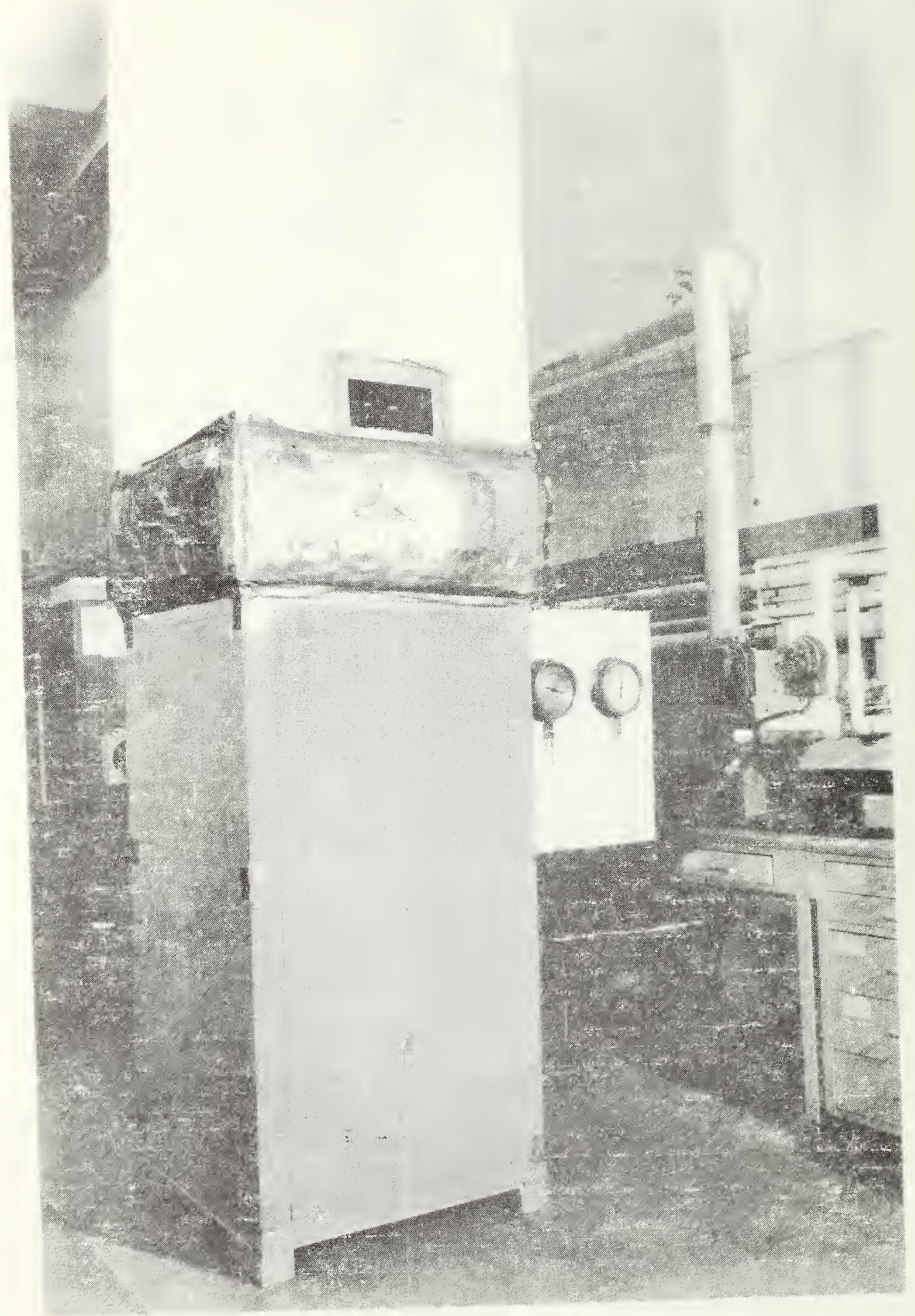

Figure 2. Heat Pump Installed in Test Apparatus 


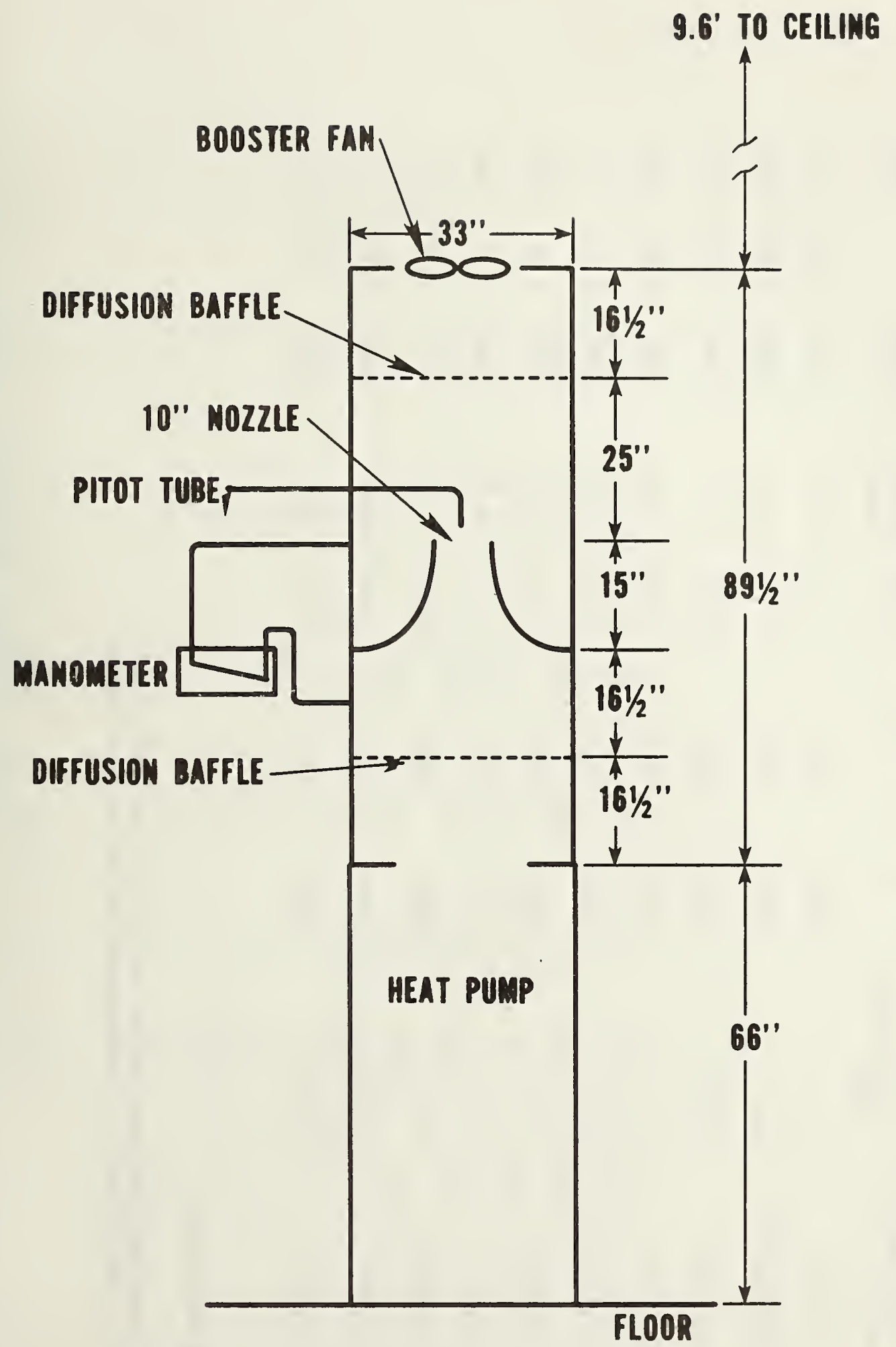

Figure 3. Air Flow Measurement Tunnel 


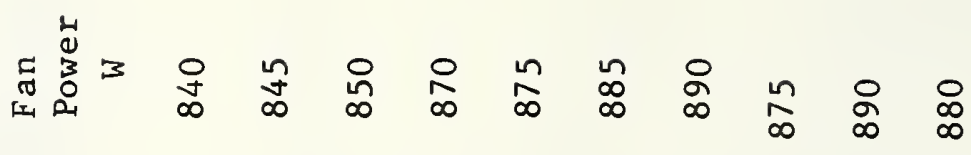

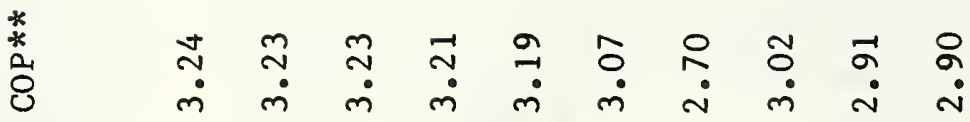

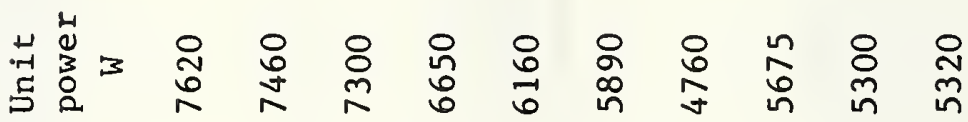

!5

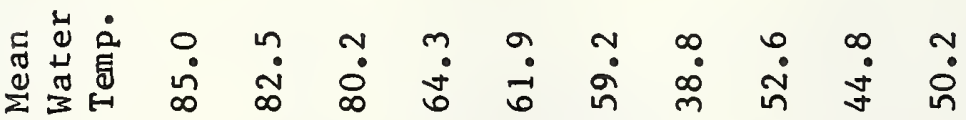

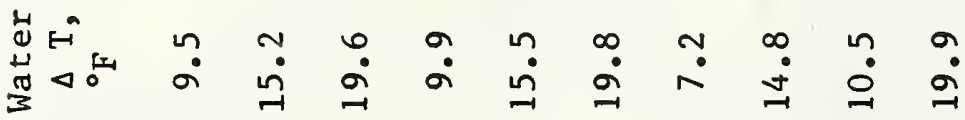

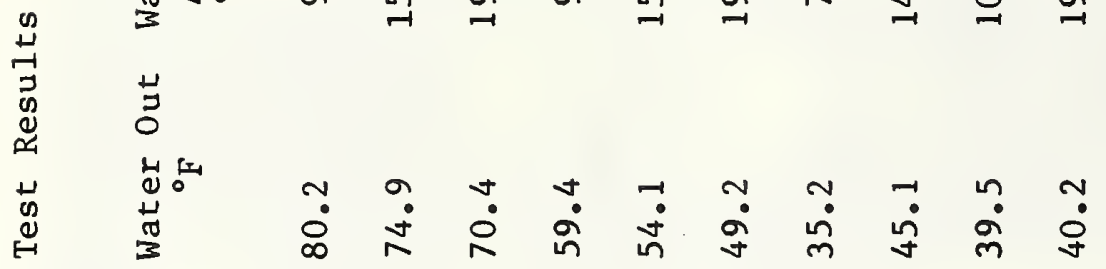

过

I

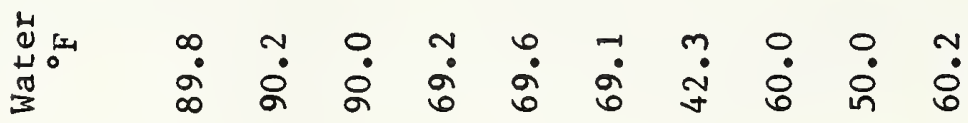

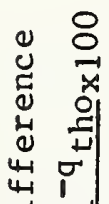

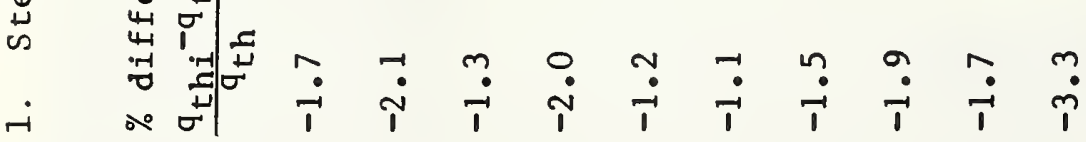

告

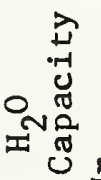

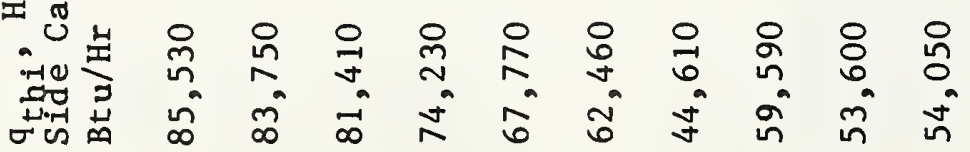

崩

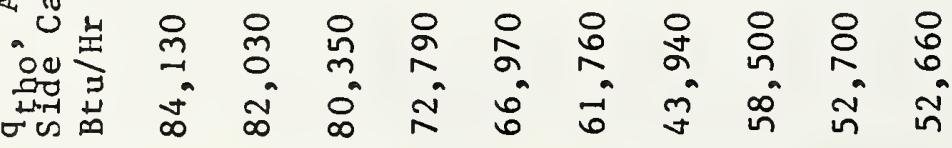

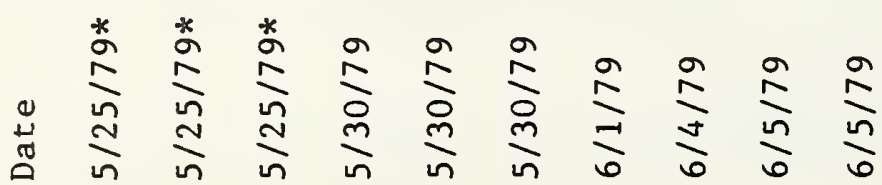

क

됴

3

걱

얼

号

ज政

to

0

नु

- 苟

. 


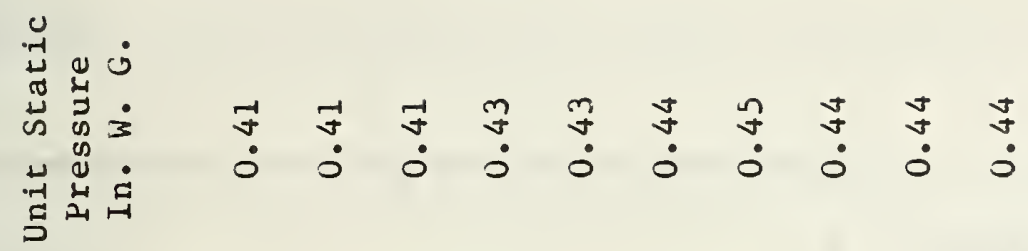

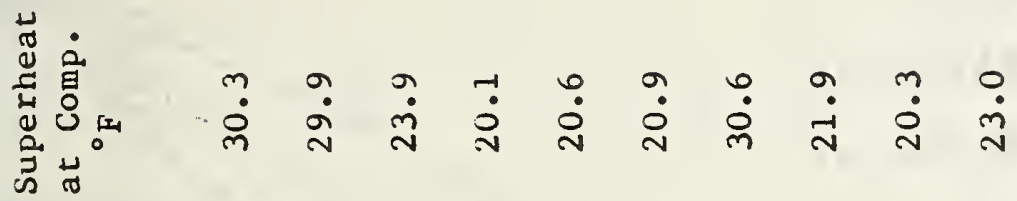

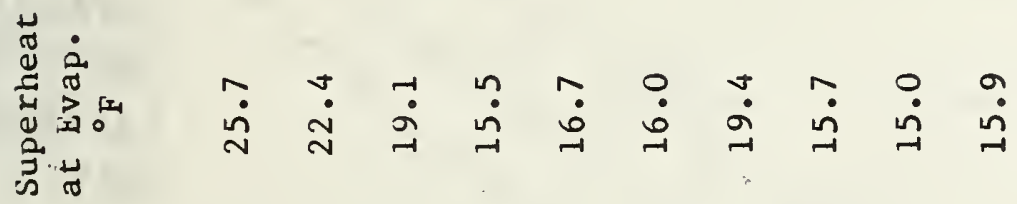

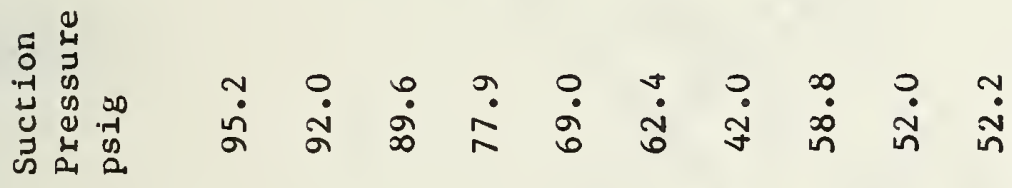

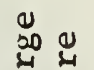

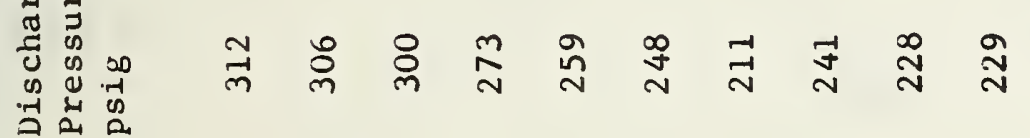

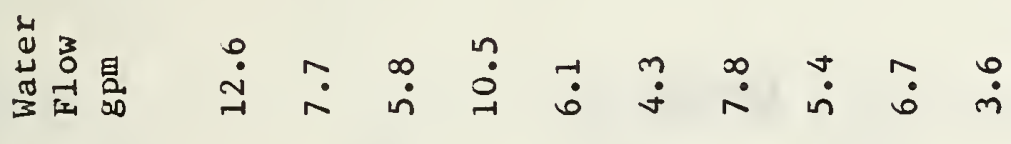

30

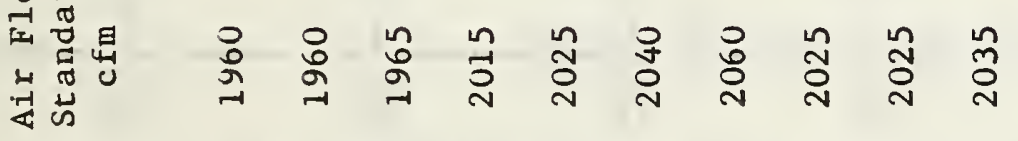

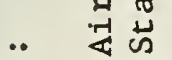

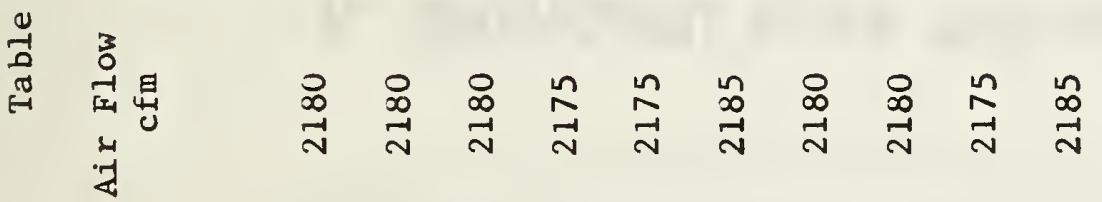

息苛

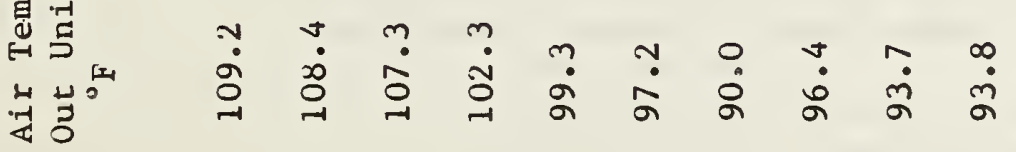

高害

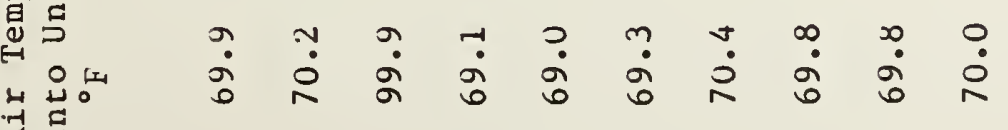

考宫

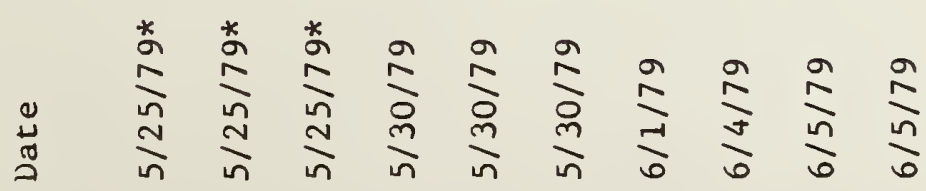




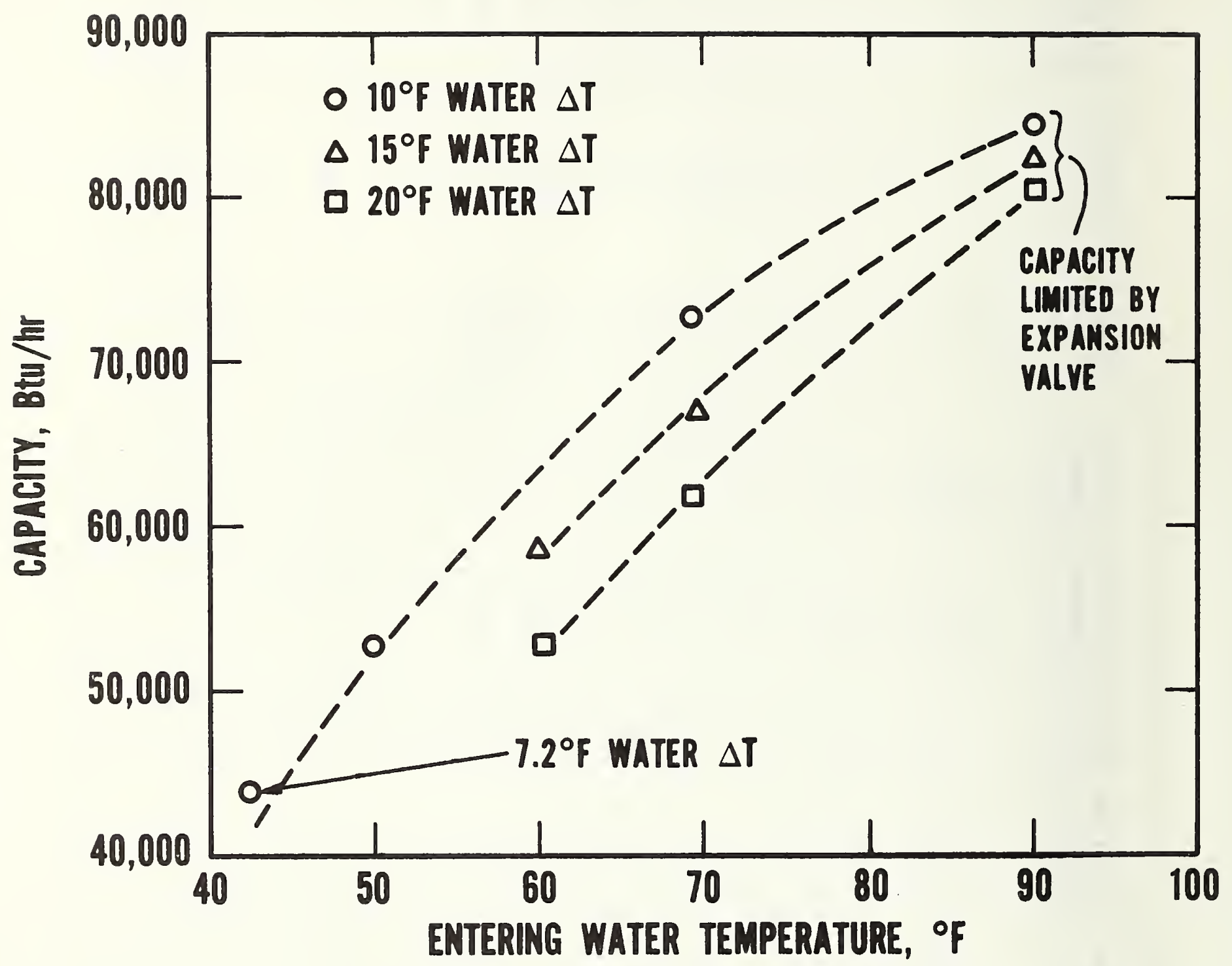

Figure 4. Variation of Heating Capacity with Entering Water Temperature for Different Inlet-to-Outlet Water Temperature

Differentials 


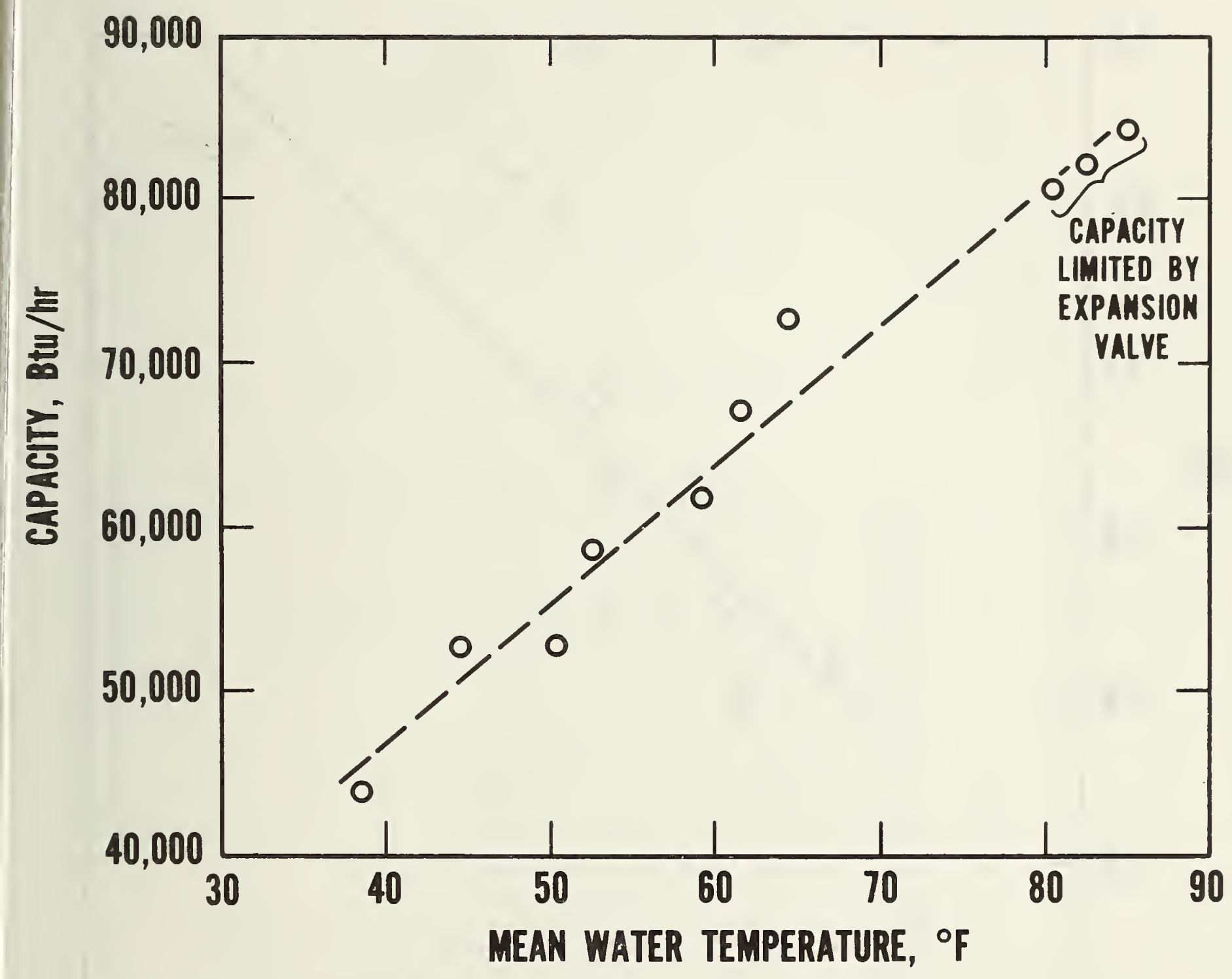

Figure 5. Variation of Heating Capacity with Mean Water Temperature 


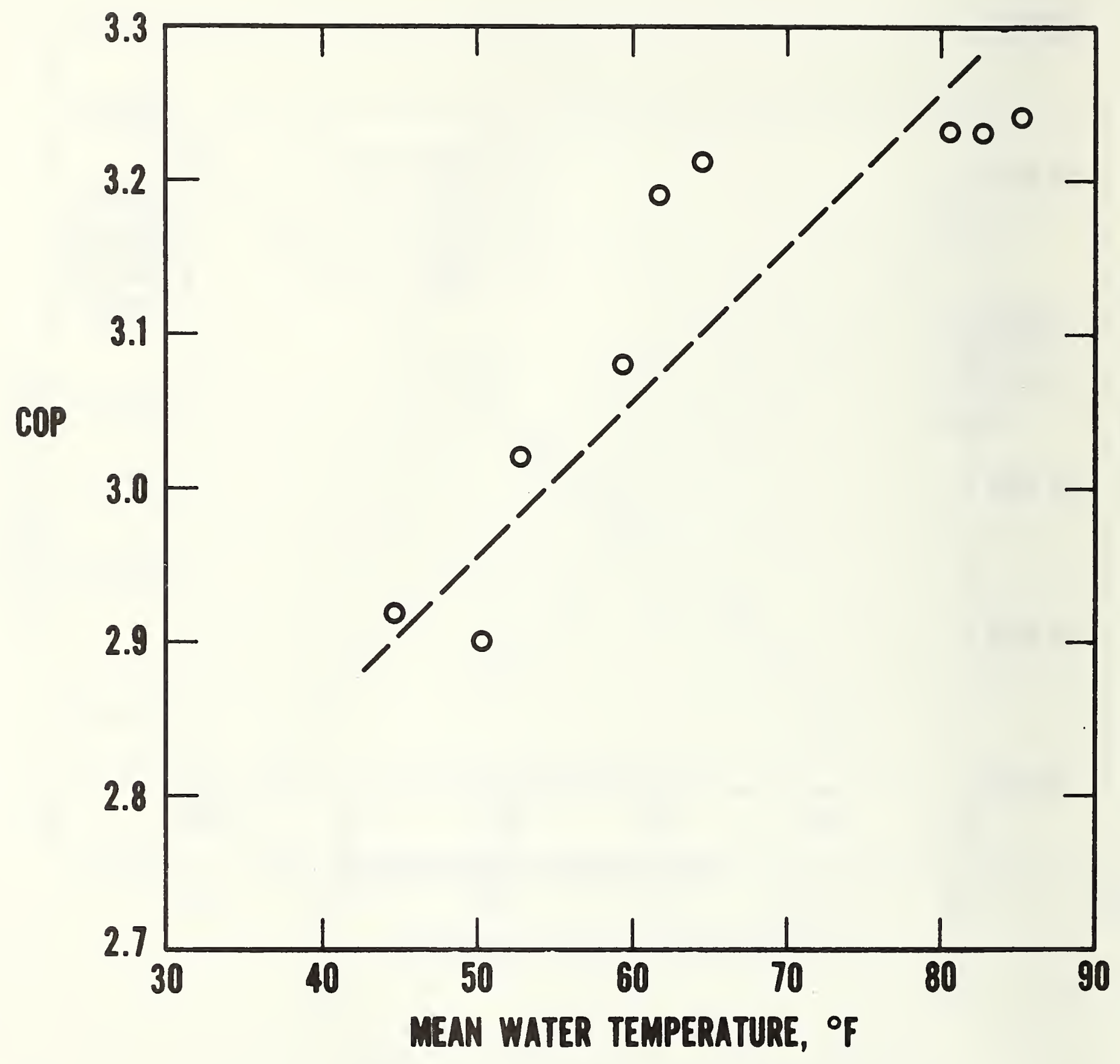

Figure 6. Variation of Heating COP with Mean Water Temperature 
离 =

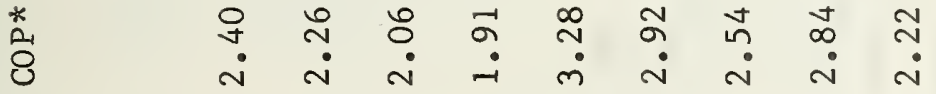

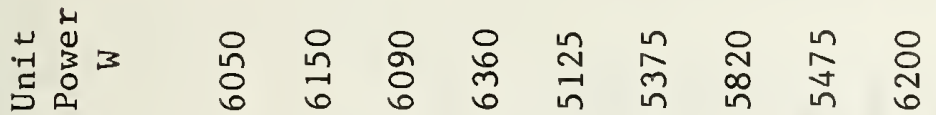

यั)

$\underset{\infty}{\infty}$

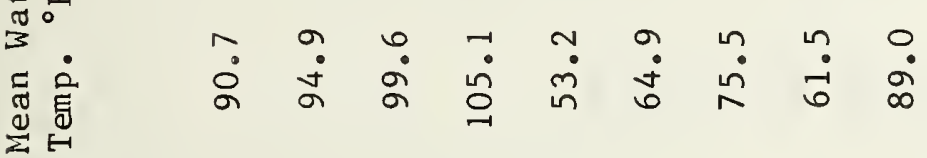

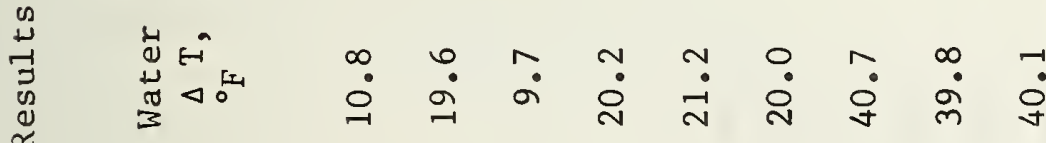

莺节

$\infty \quad+\frac{1}{0}$

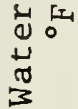

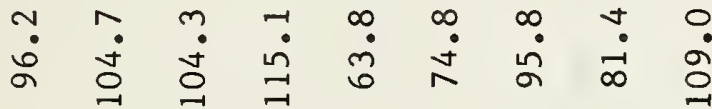

Uీ

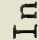

$\stackrel{0}{\Delta}$

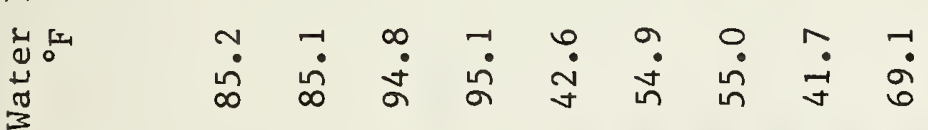

पृ प्ष

is

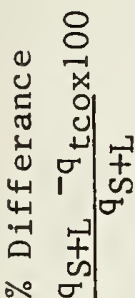

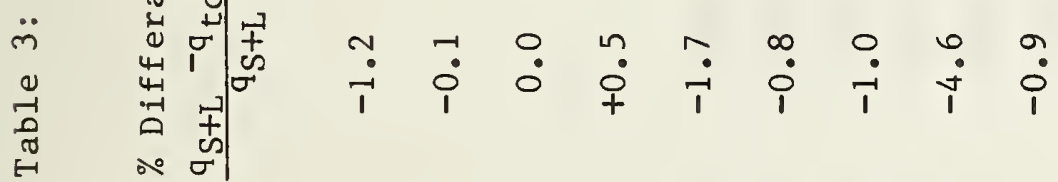

崩

点

जิ

o.

U.

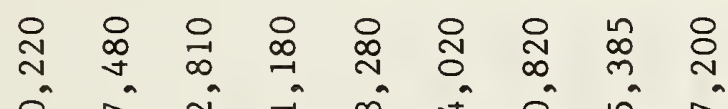

* $\rightarrow$

ช્屯

氙苔

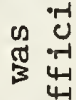

垈

30

常

त्व

式

东究

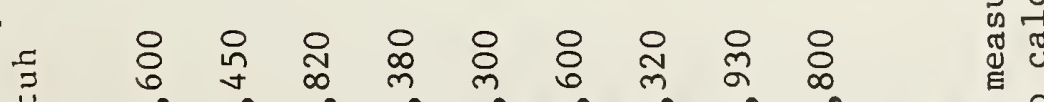

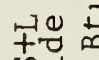

(s.-1

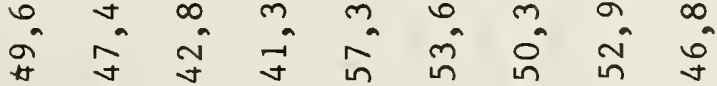

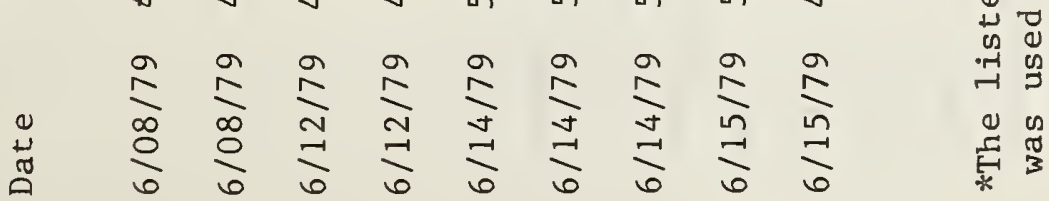




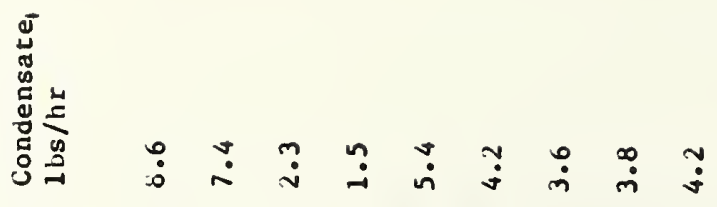

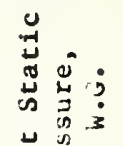

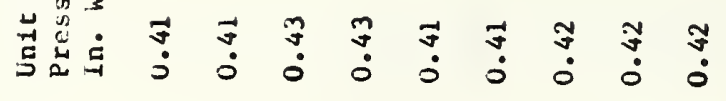

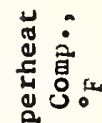

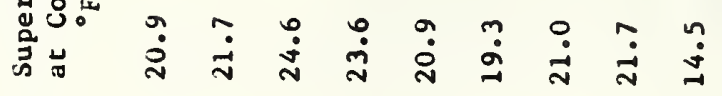

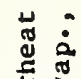

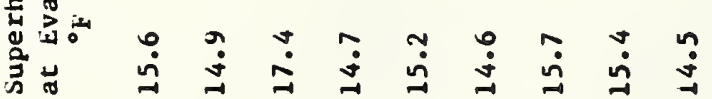

总

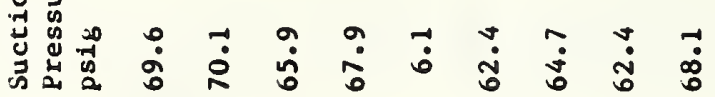

总

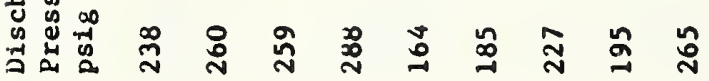

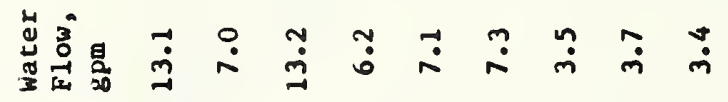

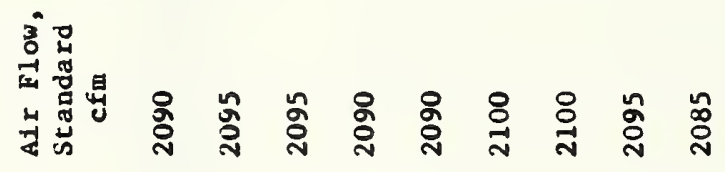

o

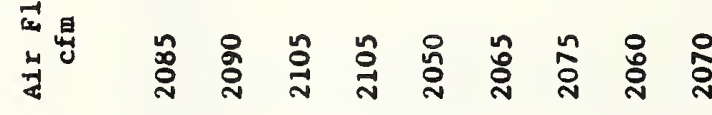

䊓

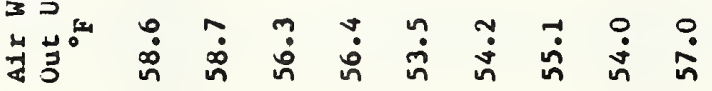

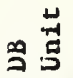

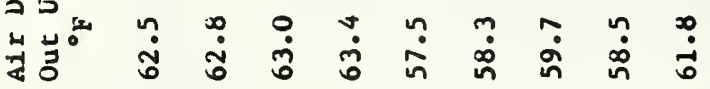

$3 \stackrel{5}{3}$

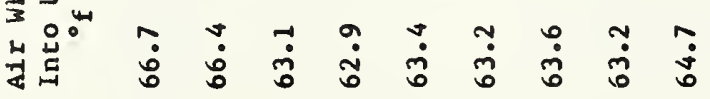

苟 站

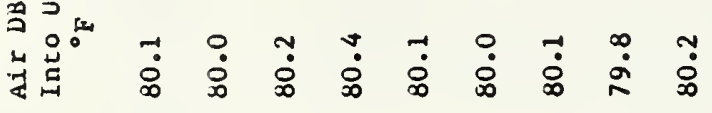

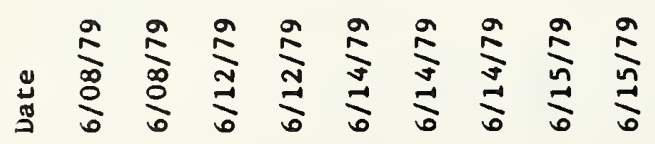




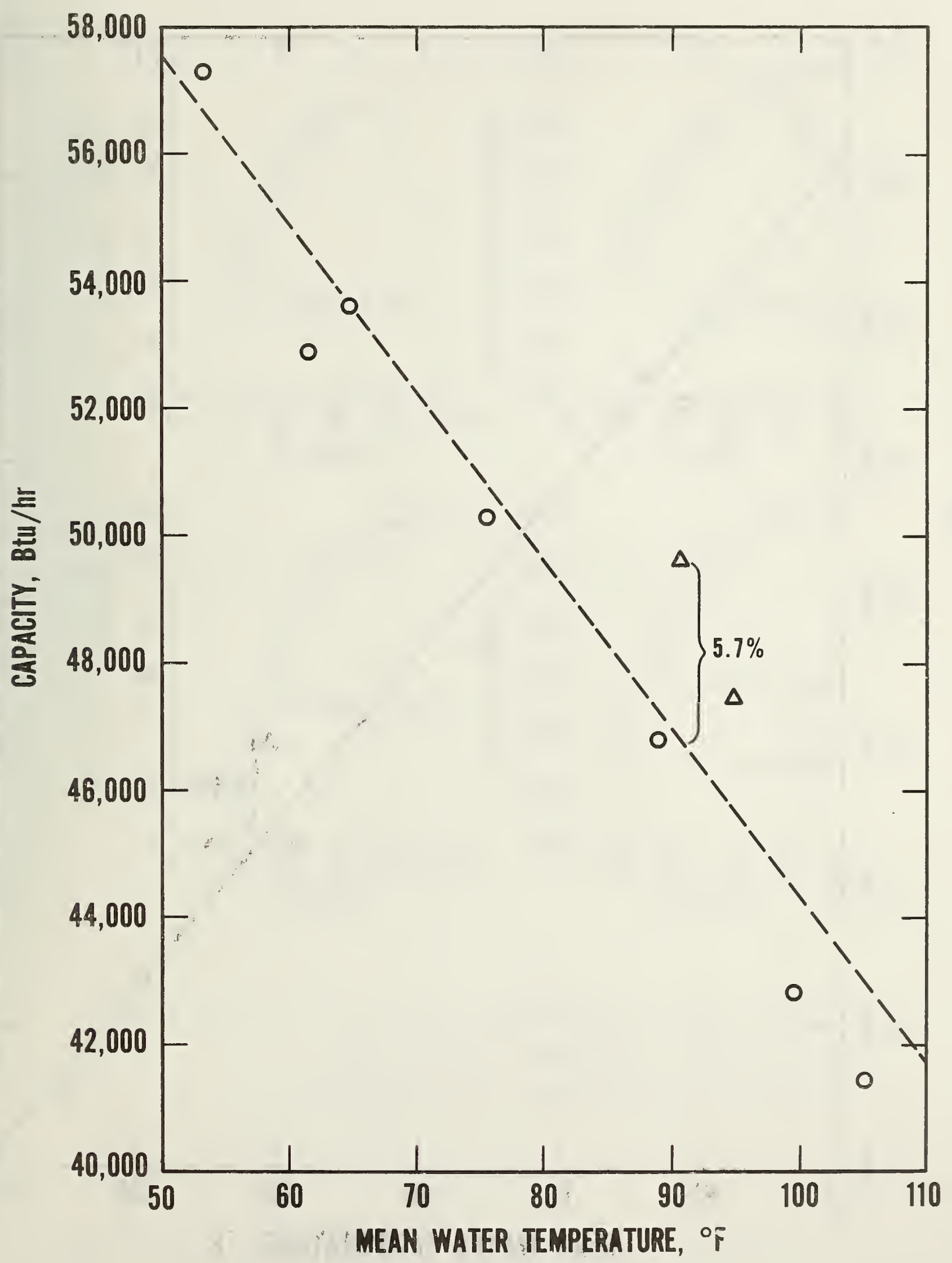

Figure 7. Variation of Cooling Capacity with Mean Water Temperature 


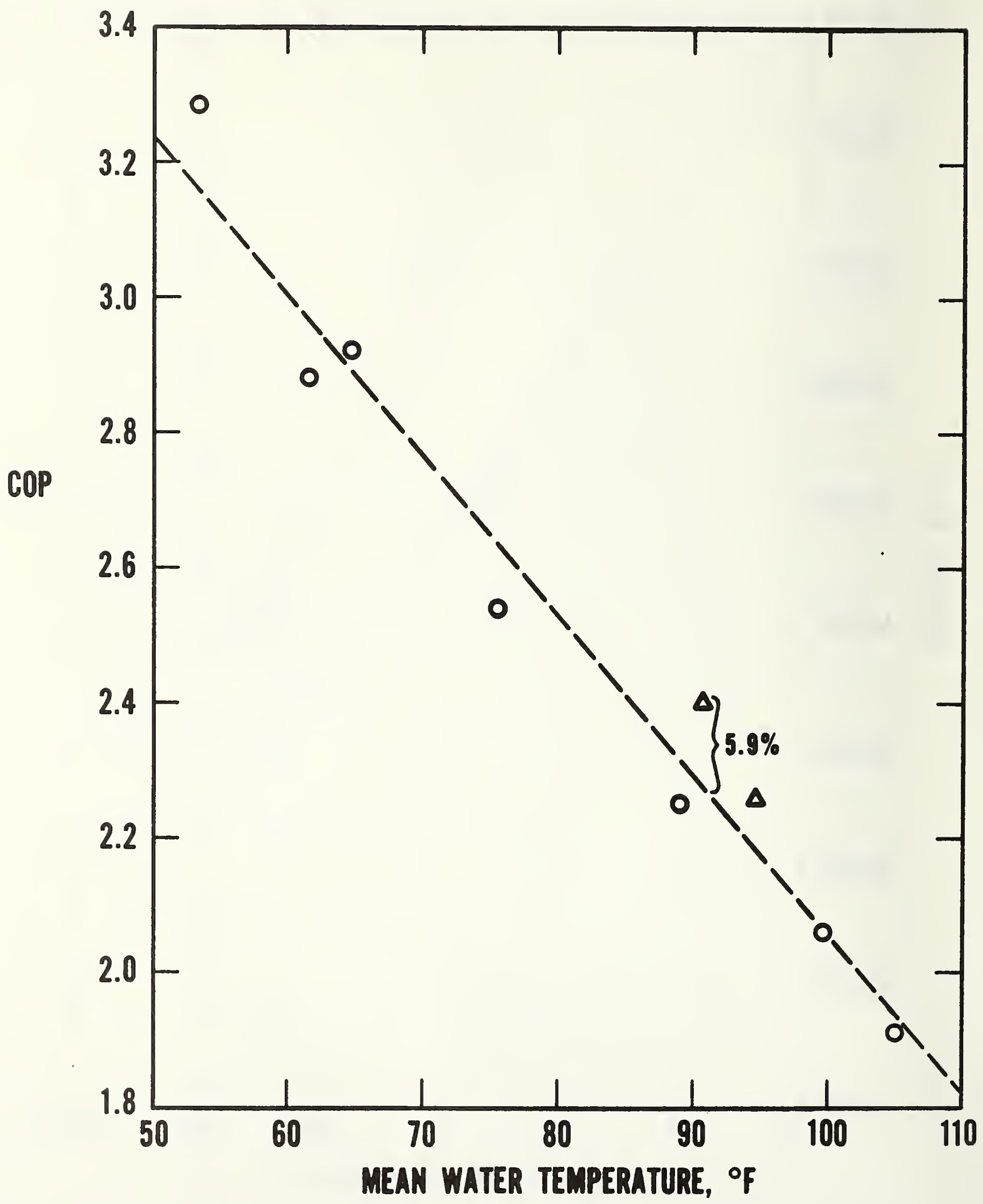

Figure 8. Variation of Cooling COP with Mean Water Temperature 

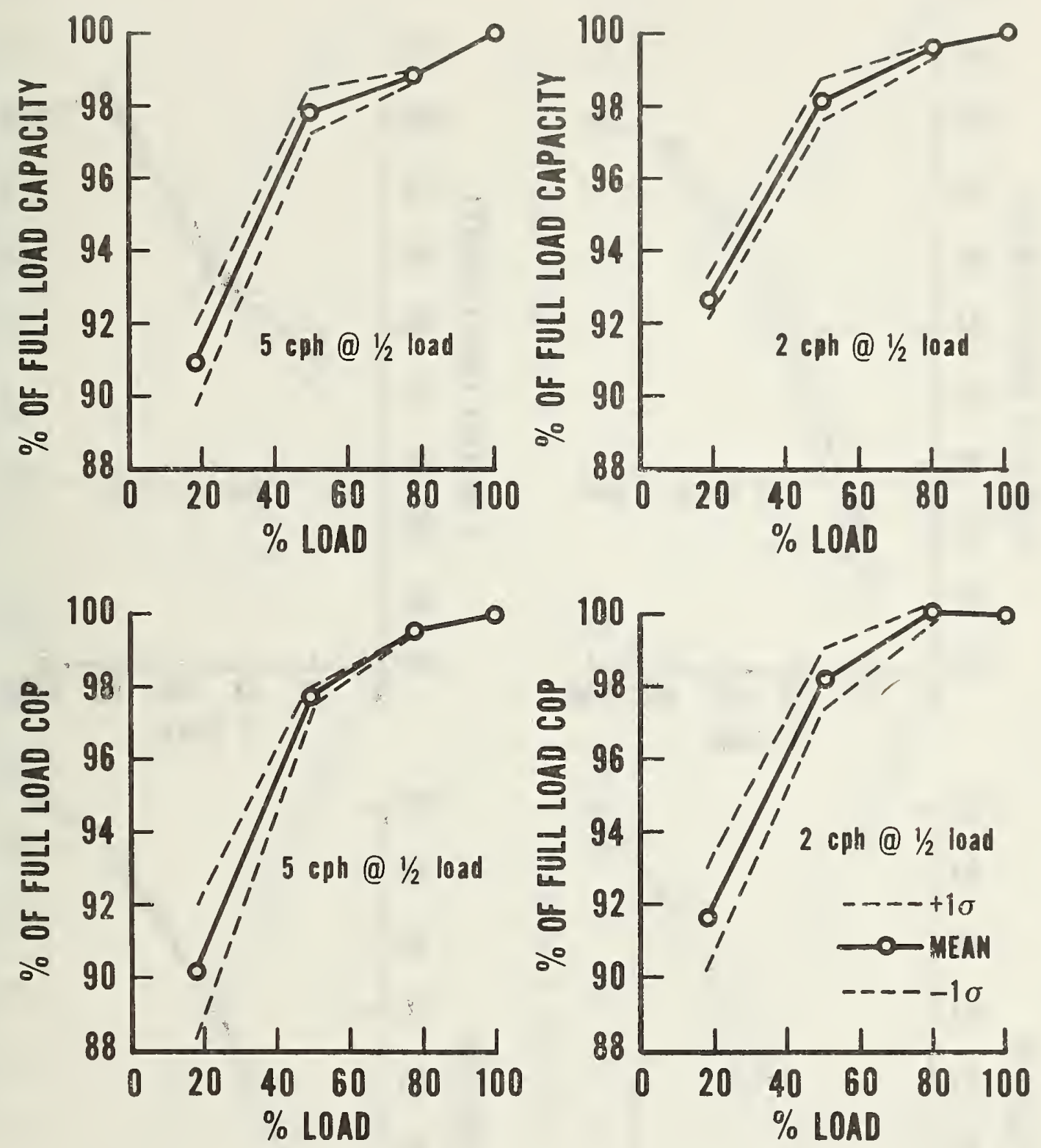

Test Conditions: Avg. Inlet Air Temperature $=69.9^{\circ} \mathrm{F}\left(21.1^{\circ} \mathrm{C}\right)$ Avg. Inlet Water Temperature $=90.0^{\circ} \mathrm{F}\left(32.2^{\circ} \mathrm{C}\right)$ Avg. Mean Water Temperature $=85.5^{\circ} \mathrm{F}\left(29.7^{\circ} \mathrm{C}\right)$

Figure 9. High Temperature Heating Cyclic Tests 

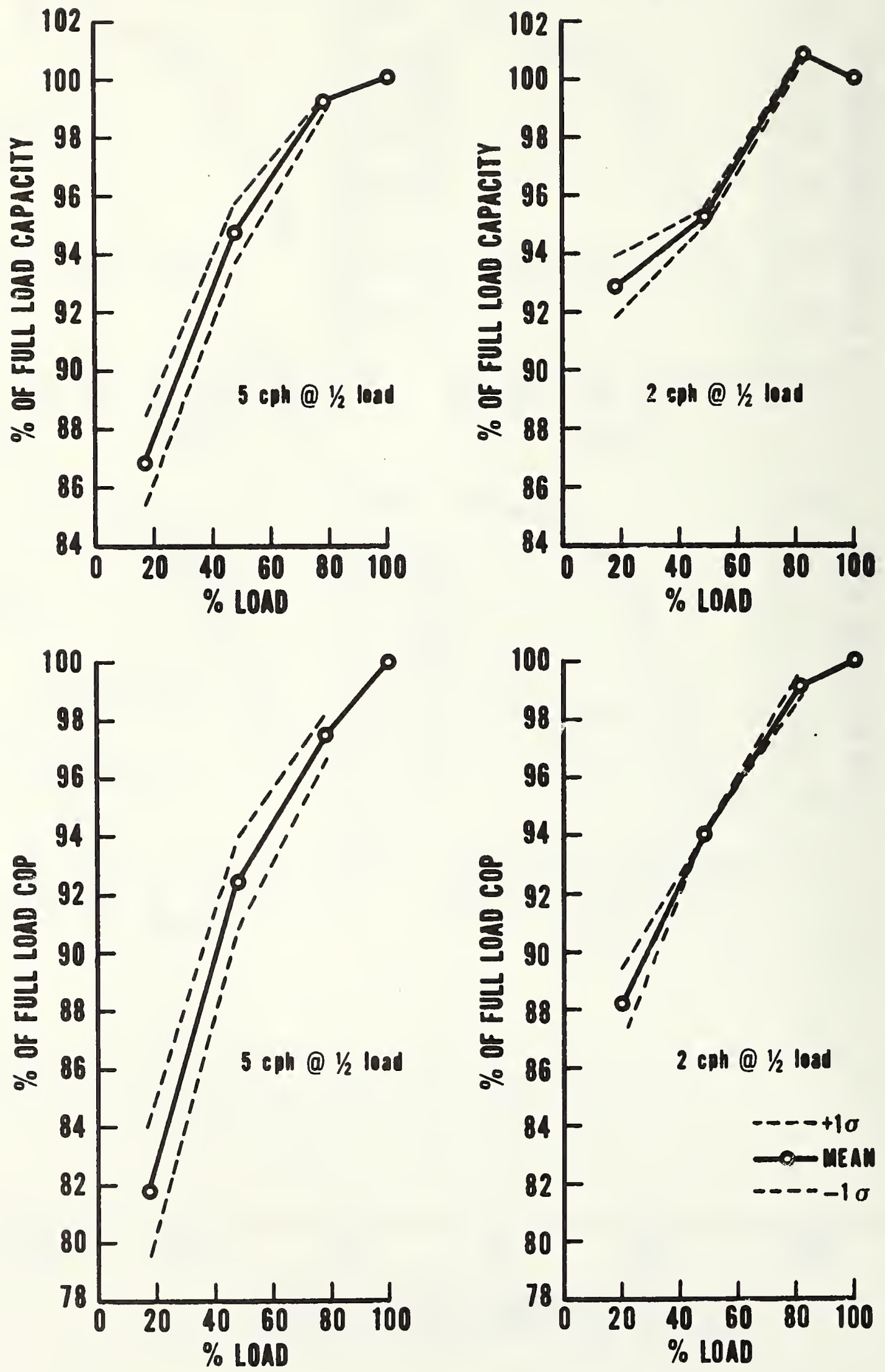

Test Conditions: Avg. Inlet Air Temperature $=69.8^{\circ} \mathrm{F}\left(21.0^{\circ} \mathrm{C}\right)$ Avg. Inlet Water Temperature $=50.0^{\circ} \mathrm{F}\left(10.0^{\circ} \mathrm{C}\right)$ Avg. Mean Water Temperature $=44.7^{\circ} \mathrm{F}\left(7.1^{\circ} \mathrm{C}\right)$

Figure 10. Low Temperature Heating Cyclic Tests 

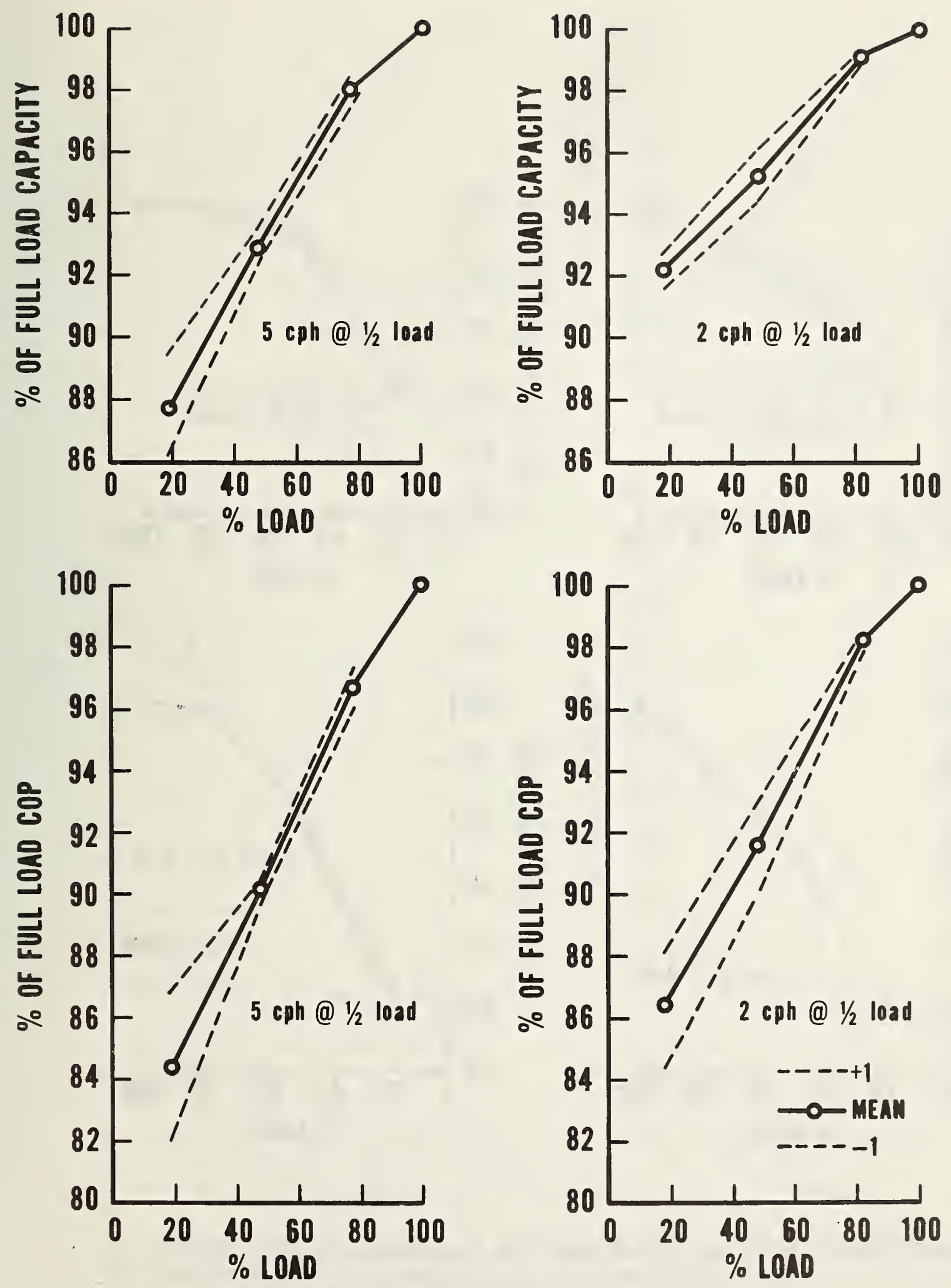

Test Conditions: Avg. Inlet Dry Bulb Air Temperature $=80^{\prime} .0^{\circ} \mathrm{F}\left(26.7^{\circ} \mathrm{C}\right)$ Avg. Inlet Wet Bulb Air Temperature $=66.8^{\circ} \mathrm{F}\left(19.3^{\circ} \mathrm{C}\right)$ Avg. Inlet Water Temperature $=90.0^{\circ} \mathrm{F}\left(32.2^{\circ} \mathrm{C}\right)$ Avg. Mean Water Temperature $=95.7^{\circ} \mathrm{F}\left(35.4^{\circ} \mathrm{C}\right)$

Figure 11. High Temperature Cooling Cyclic Tests 

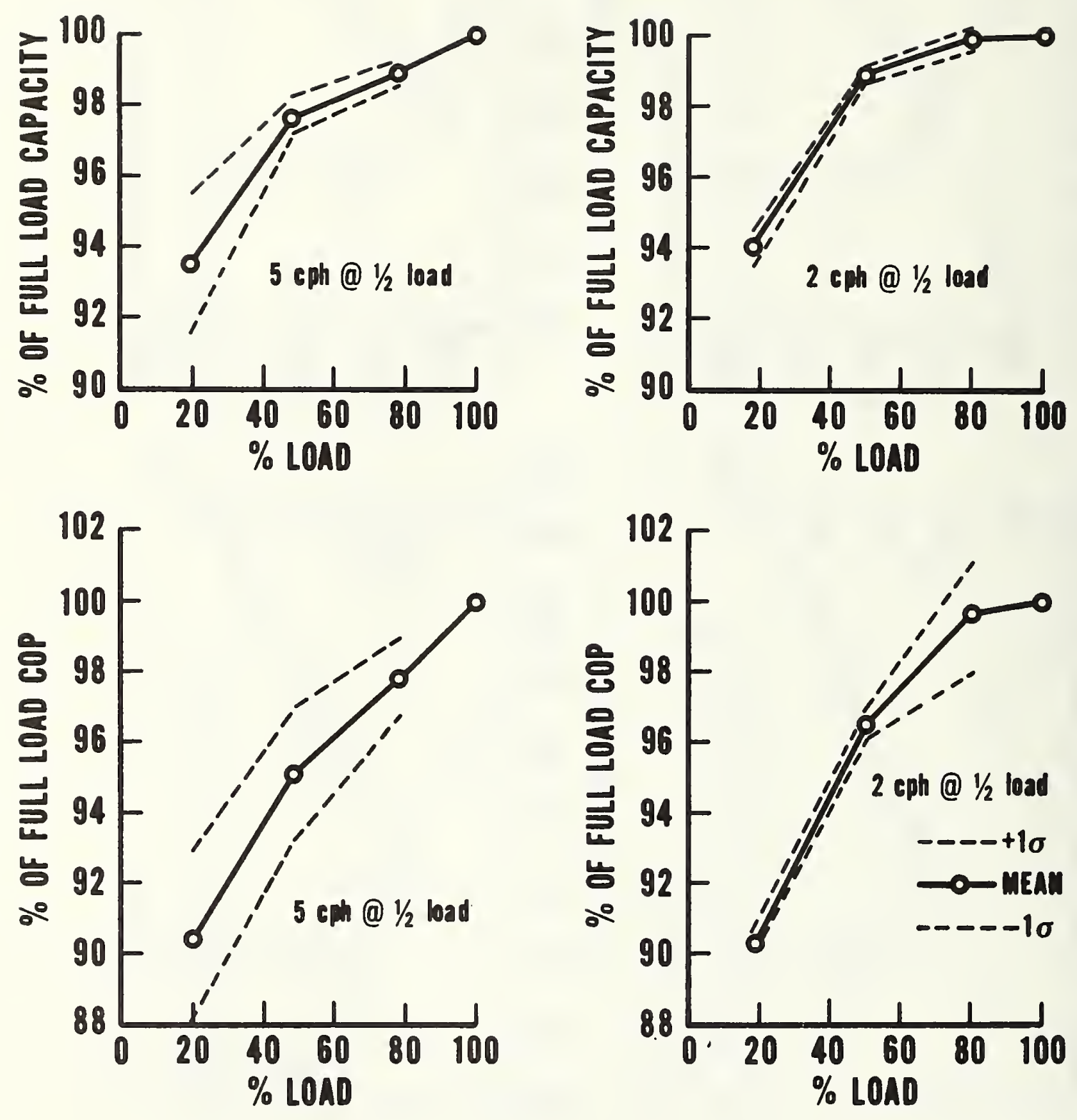

Test Conditions: Avg. Inlet Dry Bulb Air Temperature $=80.1^{\circ} \mathrm{F}\left(26.7^{\circ} \mathrm{C}\right)$ Avg. Inlet Wet Bulb Air Temperature $=65.9^{\circ} \mathrm{F}\left(18.8^{\circ} \mathrm{C}\right)$ Avg. Inlet Water Temperature $=42.1^{\circ} \mathrm{F}\left(5.61^{\circ} \mathrm{C}\right)$

Avg. Mean Water Temperature $=54.2^{\circ} \mathrm{F}\left(12.3^{\circ} \mathrm{C}\right)$

Figure 12. Low Temperature Cooling Cyclic Tests 

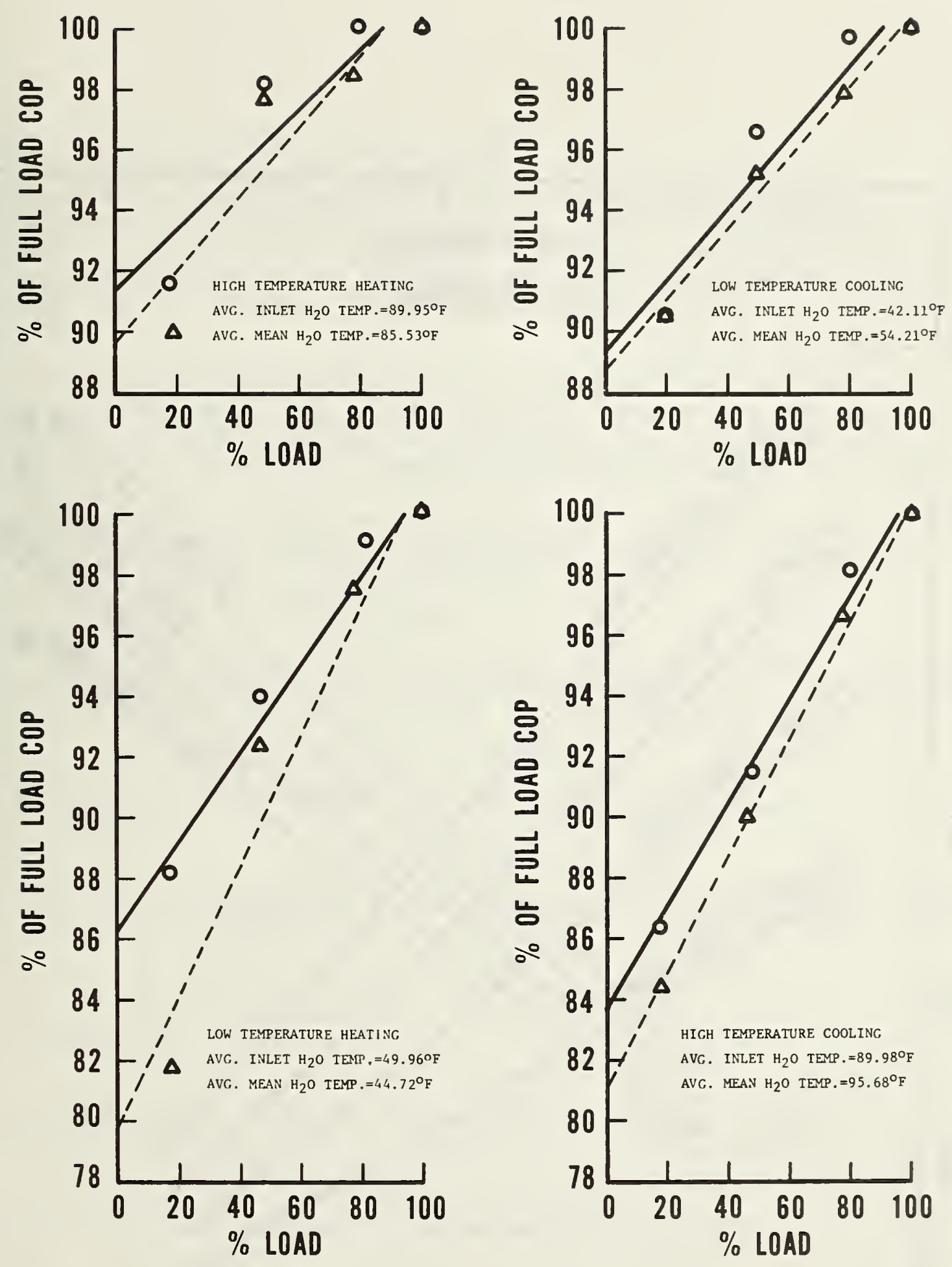

- - Cycling times of $4 \mathrm{~min}$. on $/ 15$ off, $6 \mathrm{on} / 6$ off, and $15 \mathrm{on} / 4$ off

- Cycling times of $9 \mathrm{~min}$. on $/ 38$ off, $15 \mathrm{on} / 15$ off, and $38 \mathrm{on} / 9$ off

Figure 13. Linear Regression Fit to Data on the Degradation of the Coefficient of Performance

at Part Load Operation 


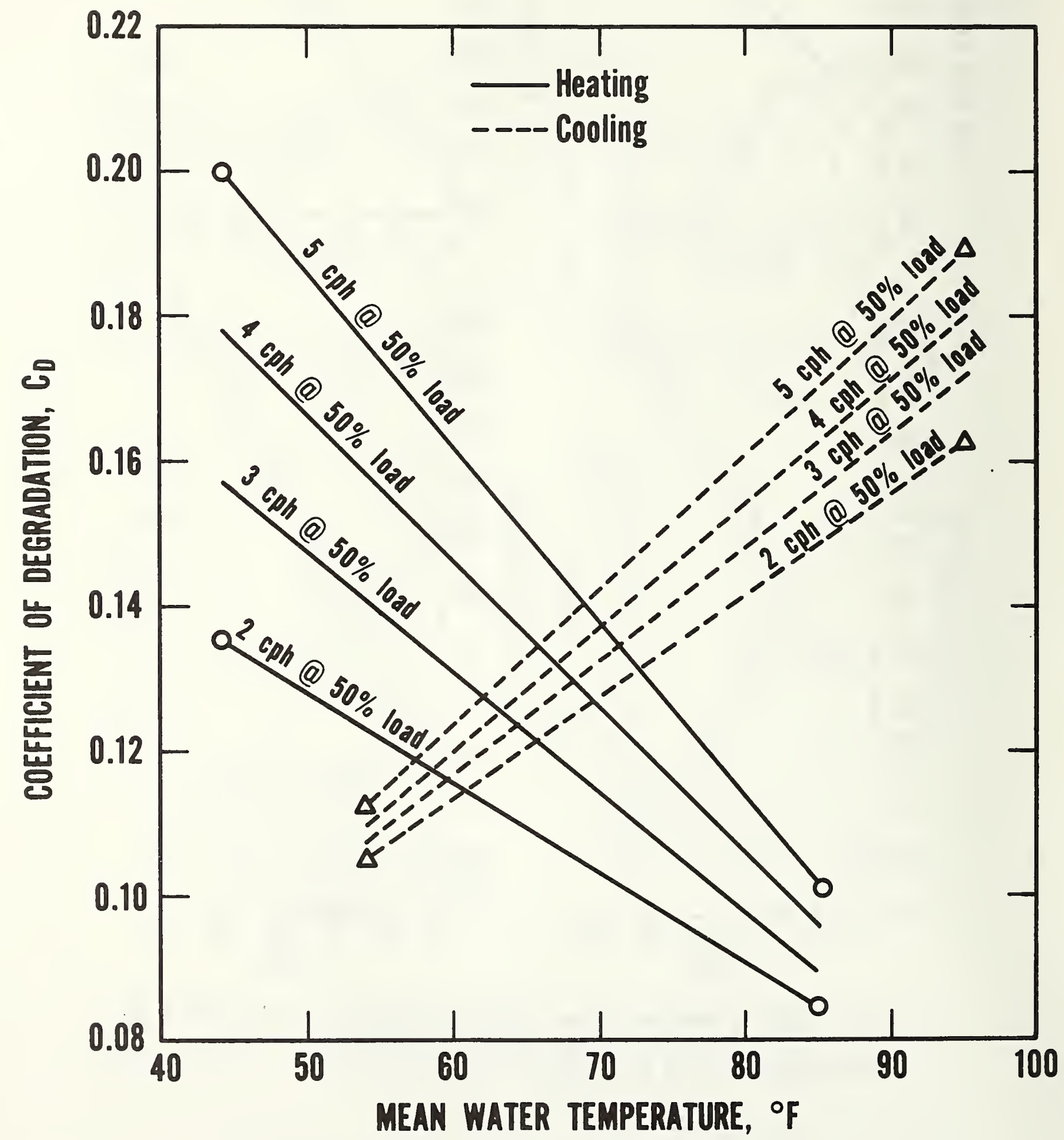

Figure 14. Variation of Coefficient of Degradation with Mean Water Temperature 
Appendix A. SEASONAL PERFORMANCE CALCULATIONS

Six representative cities were selected for seasonal performance factor calculations on the basis of design temperatures close to these tabulated in reference 10.4 and for having abundant ground water. The design conditions used in the seasonal calculations for these cities are summarized in table Al. The associated weather data for the calculations were taken directly from reference 10.3 .

Results of the seasonal calculations for the minimum building design load to which the unit is likely to be matched are given in table A2. Results when the unit is matched to the greatest likely building design load are given in table A3 and table A4. A sample calculation is shown in table A5.

The maximum, and minimum design load requirements were calculated from the following equations based on material presented in references 10.1 and 10.2

Maximum design cooling requirement $=Q_{s s, c}$

Minimum design cooling requirement $=$ the lesser of $\frac{\dot{Q}_{s s, H}\left(T-D_{2} c^{-65)}\right.}{\left(65-T_{O D, H}\right)}$ or $\dot{Q}_{s s, c}$
(Regions I, II, III, IV, VI)

Minimum design cooling requirement
(Region V)

Maximum design heating requirement $=$ the greater of $\frac{\dot{Q} s, c(65-T \text { oD, }}{\left(T_{O D},-65\right)}$ or $\dot{Q}_{s s, H}$
(Regions I, II, III, IV, VI)

Maximum design heating requirement $=$ the greater of. $2.2 Q_{S s, c}$ or $Q_{S S, H}$ (Region $\mathrm{V}$ )

Minimum design heating requirement $=$ the lesser of (Regions I, II, III, IV, VI)

$\frac{\dot{Q}_{S s, c} \quad \frac{O D, H}{O D, H}}{2\left(T_{O D, c}-65\right)}$ or $Q_{S S, H}$

Minimum design heating requirement $=$ the lesser of $Q_{\mathrm{SS}, \mathrm{c}}$ or $Q_{\mathrm{SS}, \mathrm{H}}$
(Region V)

where: $\quad Q_{\text {ss,c }}=$ Steady-state cooling capacity of unit, $\mathrm{kBtu} / \mathrm{h}$

$\dot{\mathrm{Q}}_{\mathrm{ss}, \mathrm{H}}=$ Steady-state heating capacity, of unit, $\mathrm{kBtu} / \mathrm{h}$

$\mathrm{T}_{\mathrm{OD}, \mathrm{C}}=$ Temperature, outdoor design, cooling, ${ }^{\circ} \mathrm{F}$

$\mathrm{T}_{\mathrm{OD}, \mathrm{H}}=$ Temperature, outdoor design, heating, ${ }^{\circ} \mathrm{F}$ 
The above equations differ from these presented in 10.2 in that $Q_{s s, c}$ is to be calculated at a specific application water temperature. In reference $10.2 \mathrm{Q}_{\mathrm{SS}, \mathrm{H}}$ is taken at the $47^{\circ} \mathrm{F}$ rating point value, the value of $Q_{S s, c}$ is assumed to be equal to $\mathrm{Q}_{\mathrm{SS}, \mathrm{H}}$, and $\mathrm{T}_{\mathrm{OD}, \mathrm{C}}$ is assumed to be $95^{\circ} \mathrm{F}$ for all regions.

The above minimum and maximum design heating and cooling requirements were developed on the basis that:

1. The unit may be sized to meet either the design cooling or heating load.

2. The building heat gain per degree fahrenheit in the cooling season will range from approximately equal to, to twice the building heat loss per degree fahrenheit in the heating season.

The seasonal performance loss at the minimum design load (table A2) is totally at.tributable to part-load performance degradation which is at its maximum. Consequently, this comparison shows not only the maximum value of seasonal performance factor degradation due to part-load performance degradation but also the maximum error that would occur in the seasonal performance factor calculation if the part-load performance degradation were not accounted for.

Table A 3 and $A 4$ compare bin calculations at the maximum heating and cooling design loads respectively to the steady-state COP. Tables A3 and A4 can be used to compare seasonal performance factors calculated for maximum and minimum design heating and cooling loads.

The comparison to the steady-state COP in table A4 is not a valid comparison of calculation procedures with and without part-load performance degradation. A valid comparison would require a bin calculation of seasonal performance degradation due to resistance heat only. The purpose of comparison to the steady-state COP in this table is to provide a uniform basis of comparison with the seasonal losses at the building loads used in preparing table A2.

The unit capacity and $C O P$ were calculated in each region from linear regression fits to the data presented in figures $5,6,7$, and 8 . These are:

$$
\begin{aligned}
& Q_{\text {Ss }, c}, \text { Btuh }=70,794-265.4 T_{m} \\
& \mathrm{COP}_{\text {Ss, }}=4.419-0.0236 \mathrm{~T}_{\mathrm{m}} \\
& \dot{\mathrm{Q}}_{\mathrm{SS}, \mathrm{H}}, \text { Btuh }=13,010+848.7 \mathrm{~T}_{\mathrm{m}} \\
& \mathrm{COP}_{\mathrm{ss}, \mathrm{H}}=2.030+0.0184 \mathrm{~T}_{\mathrm{m}}
\end{aligned}
$$

where $\mathrm{T}_{\mathrm{m}}$ is the mean water temperature, ${ }^{\circ} \mathrm{F}$, the average of the water temperature in and out the unit. The mean water temperature was calculated from the entering water temperature presented in table Al as follows: 
It was assumed for the sample calculation that the water flow rate for all applications was equal to that at the ARI cooling rating point, i.e., with an entering water temperature of $85^{\circ} \mathrm{F}$ and a leaving water temperature of $95^{\circ} \mathrm{F}$. This resulted in a water flow of:

water flow rate, $1 \mathrm{bs} / \mathrm{h}=\mathrm{m}=\frac{\mathrm{Q}_{\mathrm{ss}, \mathrm{c}}}{\mathrm{C}_{\mathrm{p}} \Delta \mathrm{T}}=\frac{(70,794)-(265.4)(90)}{(1)(95-85)}=4690.8 \mathrm{lbs} / \mathrm{h}$

which is equivalent to a flow rate of $(4690.8) /(60)(8.33)=9.4 \mathrm{gpm}$.

The relationship between the mean water temperature, $\mathrm{T}_{\mathrm{m}}$, and the inlet water temperature, $\mathrm{T}_{i}$, assuming constant water flow at $4690.81 \mathrm{bs} / \mathrm{hr}$, was then calculated for cooling by solving simultaneously the two equations:

$$
\begin{aligned}
& \dot{Q}_{\mathrm{ss}, \mathrm{c}}=70,794-265.4 \mathrm{~T}_{\mathrm{m}, \mathrm{c}} \\
& \dot{Q}_{\mathrm{ss}, \mathrm{c}}=\dot{\mathrm{m}} \mathrm{C}_{\mathrm{p} \Delta \mathrm{T}}=(4690.8)(1)\left[( 2 ) \left(\mathrm{T}_{\mathrm{m}, \mathrm{c}}{ }^{\left.\left.-\mathrm{T}_{\dot{i}}\right)\right]}\right.\right.
\end{aligned}
$$

giving:

$$
\mathrm{T}_{\mathrm{m}, \mathrm{c}}=\left(70,794+9381.6 \mathrm{~T}_{\mathbf{i}}\right) /(9647)
$$

Similarly for heating operation the two equations:

$$
\begin{aligned}
& \dot{\mathrm{Q}}_{\mathrm{SS}, \mathrm{H}}=13,010+848.7 \mathrm{~T}_{\mathrm{m}, \mathrm{H}} \\
& \dot{\mathrm{Q}}_{\mathrm{SS}, \mathrm{H}}=\dot{\mathrm{m}} \mathrm{Cp}_{\mathrm{p}} \mathrm{T}=(4690.8)(1)\left[2\left(\mathrm{~T}_{\mathrm{i}}-\mathrm{T}_{\mathrm{m}, \mathrm{H}}\right)\right]
\end{aligned}
$$

give:

$$
T_{m, H}=\left(9381.6 T_{i}-13,010\right) /(10,230)
$$

Using the above equations $\mathrm{T}_{\mathrm{m}}$ was calculated for each city and then, using $\mathrm{T}_{\mathrm{m}}$, the capacity and COP were calculated using the previously given linear regression algorithms and $C_{D}$ calculated by linear interpolation of the data given in section 6 . These quantities were in turn used in conjunction with weather data from reference 3 to calculate the seasonal performance of the unit.

As a sample, the calculation procedure for the city chosen as representative of region IV, Dayton, Ohio, will be presented in detail.

The inlet water temperature for Dayton was assumed to be $53^{\circ} \mathrm{F}$. This results in a cooling mean water temperature, $\mathrm{T}_{\mathrm{m}, \mathrm{c}}$, of

$\mathrm{T}_{\mathrm{m}, \mathrm{c}}=[(70,794)+(9381.6)(53)] /(9647)=58.88^{\circ} \mathrm{F}$

Using this mean water temperature, the steady-state cooling capacity and COP may be calculated as: 


$$
\begin{aligned}
\AA_{\text {ss }, c} & =(70,794)-(265.4)(58.88)=55.167 \mathrm{kBtu} / \mathrm{h} \\
\operatorname{COP}_{\text {ss , }} & =(4.419)-(0.0236)(58.88)=3.029 .
\end{aligned}
$$
From these two quantities the steady-state cooling power draw, $E_{s s, c}$, may
be calculated:

$$
\dot{E}_{s s, c}=\frac{\dot{Q}_{s s, c}}{3.413 \mathrm{COP}_{s s, c}}=\frac{(55.167)}{(3.413)(3.029)}=5.336 \mathrm{~kW}
$$

Similarly for heating:

$$
\begin{aligned}
T_{\mathrm{m}, H} & =[(9381.6)(53)-(13,010)] /(10,230)=47.33^{\circ} \mathrm{F} \\
\dot{Q}_{\mathrm{SS}, H} & =(13,010)+(848.7)(47.33)=53.179 \mathrm{kBtu} / \mathrm{h} \\
\mathrm{COP}_{\mathrm{SS}, \mathrm{H}} & =(2.030)+(0.0184)(47.33)=2.898 \\
\dot{\mathrm{E}}_{\mathrm{SS}, \mathrm{H}} & =\frac{(53.179)}{(3.413)(2.898)}=5.376 \mathrm{~kW}
\end{aligned}
$$

Next, the degradation coefficients were calculated by linear interpolation of the data presented in section 6. As an example, for a cycling rate of $2 \mathrm{cph}$ at $50 \%$ load a value of $C_{D}$ of 0.163 was measured at a $95.68^{\circ} \mathrm{F}$ mean water temperature, and a value of $C_{p}$ of 0.105 was measured at a 54.21 mean water temperature. These data can be combined into a linear interpolation formula as:

$$
C_{D}=0.105+\frac{(0.163-0.105)}{(95.68-54.21)}(58.88-54.21)=0.112
$$

The other required $C_{p}$ values for this region were similarly calculated and are summarized as follows:

\begin{tabular}{ll} 
& \multicolumn{1}{c}{$C_{D}$} \\
Cooling, $2 \mathrm{cph}$ at $50 \%$ load & 0.112 \\
Cooling, $5 \mathrm{cph}$ at $50 \%$ load & 0.121 \\
Heating, $2 \mathrm{cph}$ at $50 \%$ load & 0.132 \\
lleating, $5 \mathrm{cph}$ at $50 \%$ load & 0.194
\end{tabular}

The building loads for which seasonal calculations were to be performed were calculated using the previously given formulae and were then rounded to the standardized values given in references 2 and 4 . 
The maximum design cooling requirement was equal to $Q_{\mathrm{Ss}, \mathrm{c}}=55.167 \mathrm{kBtu} / \mathrm{h}$ rounded to $60 \mathrm{kBtu} / \mathrm{h}$.

The minimum design cooling requirement was equal to the lesser of $Q_{s s, H}\left(T_{Q P,}-65\right) /\left(65-T_{O p, H}\right)=(53.179)(89-65) /(65-4)=20.923 \mathrm{kBtu} / \mathrm{h}$ or $\mathrm{Q}_{\mathrm{ss}, \mathrm{C}}^{\mathrm{SS}, \mathrm{H}}=55: 167 \mathrm{kBtu} / \mathrm{h}$ which is $20.923 \mathrm{kBtu} / \mathrm{h}$ rounded to $20 \mathrm{kBtu} / \mathrm{h}$.

The maximum design heating requirement was equal to the greater of

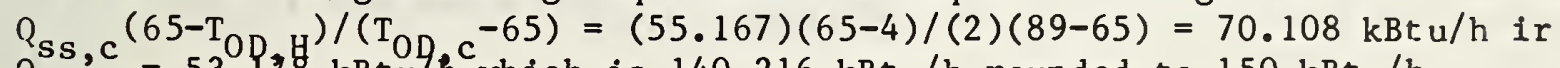
$\mathrm{Q}_{\mathrm{ss}, \mathrm{H}}=53.178 \mathrm{kBtu} / \mathrm{h}^{\mathrm{c}}$ which is $140.216 \mathrm{kBtu} / \mathrm{h}$ rounded to $150 \mathrm{kBtu} / \mathrm{h}$.

The minimum design heating requirement was equal to the lesser of $Q$

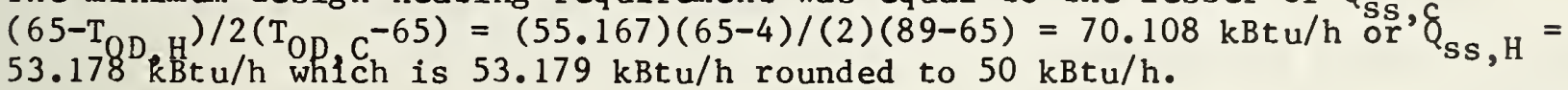

The sample bin method seasonal calculations in table A5 were performed at the maximum design cooling requirement, $60 \mathrm{kBtu} / \mathrm{h}$, and the maximum design heating requirement, $150 \mathrm{kBtu} / \mathrm{h}$.

In table $A 5$ the representative bin outdoor temperatures, $t_{j}$, and fractional bin hours, $n_{j} / N$, were obtained from the data presented in reference $3 . t_{j}$ is the average temperature for each of the $5 \%$ bins of reference $3 . n_{j} / \mathrm{N}^{j}$ was obtained by dividing the number of hours in each bin by the total number of hours above $65^{\circ} \mathrm{F}$ for the cooling bins and the total number of hours below $65^{\circ} \mathrm{F}$ for the heating bins.

The building loads as a function of temperature for cooling, $B L_{c}\left(t_{j}\right)$, and heating $\mathrm{BL}_{\mathrm{H}}\left(t_{j}\right)$, were calculated by the following equations:

$$
B_{C}\left(t_{j}\right)=\frac{\left(T_{j}-65\right)}{\left(C_{c}\right)\left(T_{O D}, c^{-65)}\right.}(D C R) \text {, }
$$

and

$$
\mathrm{BL}_{\mathrm{H}}\left(t_{j}\right)=\frac{\left(65-\mathrm{T}_{j}\right)}{\left(65-\mathrm{T}_{\mathrm{OD}, \mathrm{H}}\right)}\left(\mathrm{C}_{\mathrm{H}}\right)(\mathrm{DHR}) \text {, }
$$

where $\mathrm{C}_{\mathrm{c}}$ and $\mathrm{C}_{\mathrm{H}}$ are experience factors which tend to improve the agreement between calculated and measured building loads. Recommended values (references 1 and 2 ) are $C_{c}=1.1$ and $C_{H}=0.77$.

As an example, for cooling bin number 4,

$$
\mathrm{BL}_{\mathrm{C}}(82)=\frac{(82-65)}{(1.1)(89-65)}(60)=38.636 \mathrm{kBtu} / \mathrm{h} \text {, }
$$


and for heating bin number 4,

$$
\mathrm{B}_{\mathrm{L}_{\mathrm{H}}}(47)=\frac{(65-47)}{(65-4)}(0.77)(150)=34.082 \mathrm{kBt} \cdot \mathrm{u} / \mathrm{h} \cdot
$$

The next calculated quantity was the load factor, $X\left(t_{j}\right)$, equal to $B L_{c}\left(t_{j}\right) / Q_{g}$ for cooling and to $B L_{H}\left(t_{j}\right) / Q_{s s, c}$ for heating. $X\left(t_{j}\right)$ has a maximum value of $\mathcal{I}_{\bullet}, c$ For cooling bin number 4

$$
x_{c}(82)=(38.636) /(55.167)=0.700,
$$

and for heating bin number 4:

$$
\left.\mathrm{X}_{\mathrm{H}}(47)=(34.082) / 53.179\right)=0.641
$$

Next the part-load factor is calculated from the equation:

$$
\operatorname{PLF}(X)=1-C_{D}\left(1-X\left(t_{j}\right)\right) \text {. }
$$

For cooling bin number 4 with an assumed cycling rate of $2 \mathrm{cph}$ at $50 \% 10 \mathrm{ad}$ this results in:

$$
\operatorname{PLF}_{c}(82)=1-(0.112)(1-0.700)=0.966 \text {. }
$$

For heating bin number 4 with an assumed cycling rate of $2 \mathrm{cph}$ at $50 \%$ load this results in:

$$
\operatorname{PLF}_{H}(47)=1-(0.132)(1-0.641)=0.953
$$

The heat pump electrical energy input for each temperature bin is represented by the term

$$
\frac{\mathrm{n}_{j}}{\mathrm{~N}} \frac{\mathrm{X}\left(\mathrm{T}_{j}\right)}{\mathrm{PLF}(\mathrm{X})} \dot{\mathrm{E}}_{\mathrm{SS}}
$$

Continuing with the example of cooling bin number 4 with an assumed cycling rate of $2 \mathrm{cph}$ at $50 \%$ load,

$$
\frac{\mathrm{n}_{j}}{\mathrm{~N}} \frac{\mathrm{X}_{c}\left(\mathrm{~T}_{j}\right)}{\mathrm{PLF}_{c}(\mathrm{X})} \dot{\mathrm{E}} \mathrm{ss,c}=\frac{(0.143)(0.700)(5.336)}{(0.966)}=0.553
$$

and for heating bin number 4 at an assumed cycling rate of $2 \mathrm{cph}$ at 50 percent load:

$$
\frac{n_{j}}{N} \frac{X_{H}\left(T_{j}\right)}{\operatorname{PLF}_{H}(X)} \dot{E}_{S S, H}=\frac{(0.102)(0.641)(5.376)}{(0.953)}=0.369 .
$$


Note that when the building load exceeds the unit capacity, the heat pump is assumed to run continuously and $X\left(T_{j}\right)=P L F(X)=1$. In this case the heat pump electrical energy input is equal to:

$$
\frac{n_{j}}{N} \dot{E}_{S S}
$$

As an example, for heating bin number 8:

$$
\frac{\mathrm{n}_{j}}{\mathrm{~N}} \dot{\mathrm{E}}_{S S, H}=(.085)(5.376)=0.4570 \mathrm{kw}
$$

In this case, when the building heating load exceeds the unit heating capacity, it is assumed that electric resistance heaters will be used to maintain the building temperature. Their electrical power requirement is calculated as:

$$
\frac{R H}{N}=\frac{B L\left(T_{j}\right)-\dot{Q}_{s s, H}}{3.413} \frac{n_{j}}{N}
$$

Which for heating bin number 8 is equal to:

$$
\frac{\mathrm{Rll}}{\mathrm{N}}=\frac{(71.951-53.179)(0.085)}{3.413}=0.4675
$$

The fractional building load hours in each temperature bin are calculated as:

$$
\frac{n_{j}}{N} B L\left(t_{j}\right)
$$

except when $X\left(t_{j}\right)=1$ during cooling operation, in which case the fractional building load hours are:

$$
\frac{n_{j}}{Q_{s s}, c}
$$

For example, in cooling bin number 4

$$
\frac{n_{j}}{N} \operatorname{BL}\left(t_{j}\right)=(0.143)(38.636)=5.525,
$$

in cooling bin number 7

$$
\frac{\mathrm{n}_{\mathrm{j}}}{\mathrm{N}} Q_{\mathrm{SS}, \mathrm{c}}=(0.001)(55.167)=0.552,
$$


in heating bin number 4

$$
\frac{n_{j}}{N} B L\left(t_{j}\right)=(0.102)(34.082)=3.4764,
$$

and in heating bin number 8

$$
n_{N} B L\left(t_{j}\right)=(0.085)(71.951)=6.1159
$$

The seasonal performance factor is equal to the summation of the fractional building load hours divided by the summation of the total electrical energy inputs. For example, for cooling at an assumed cycling rate of $2 \mathrm{cph}$ at 50 percent 1 load:

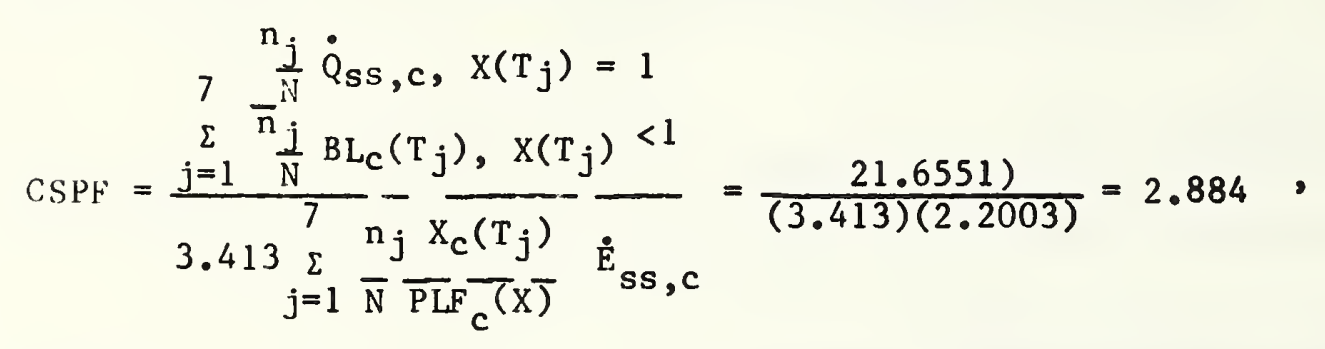

and for heating at an assumed cycling rate of $2 \mathrm{cph}$ at 50 percent load

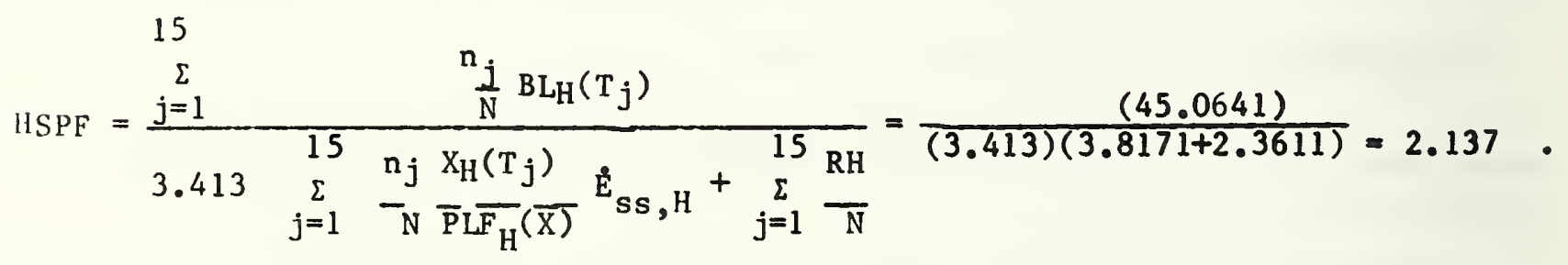




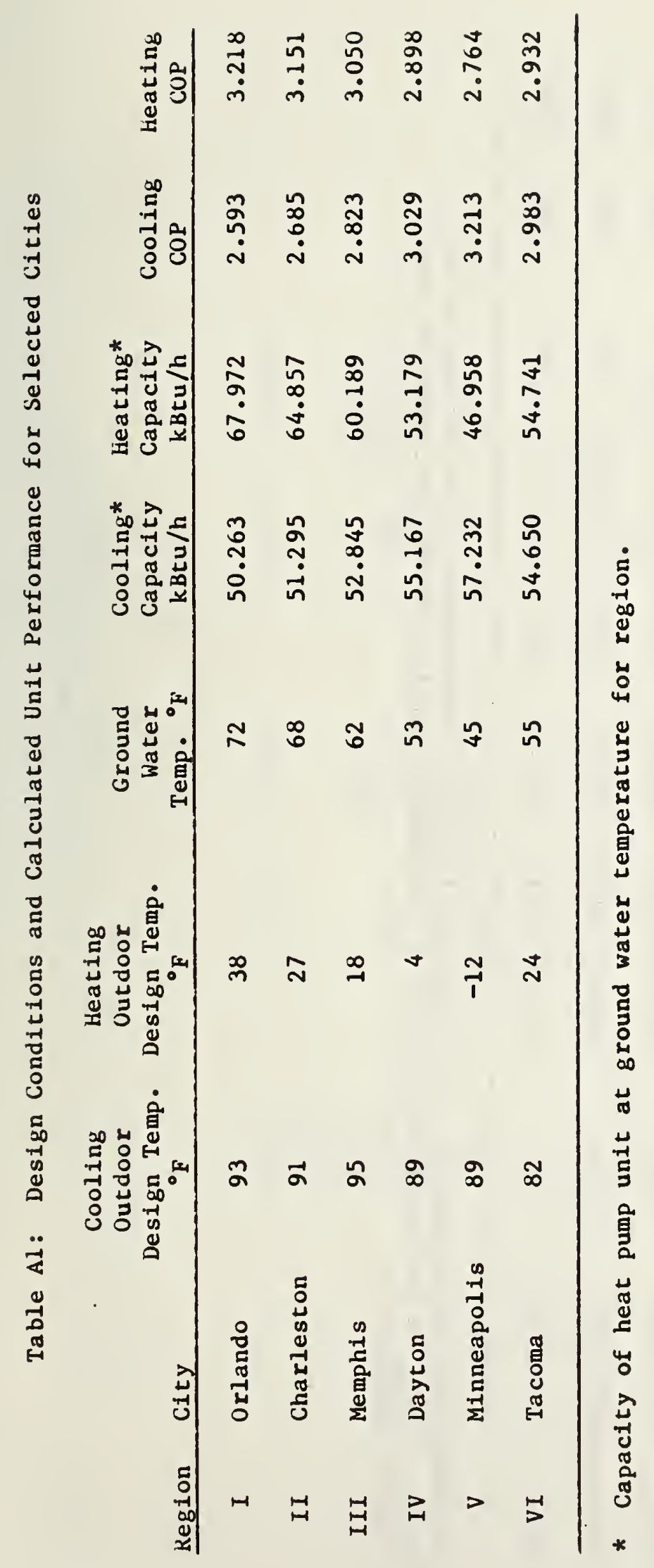




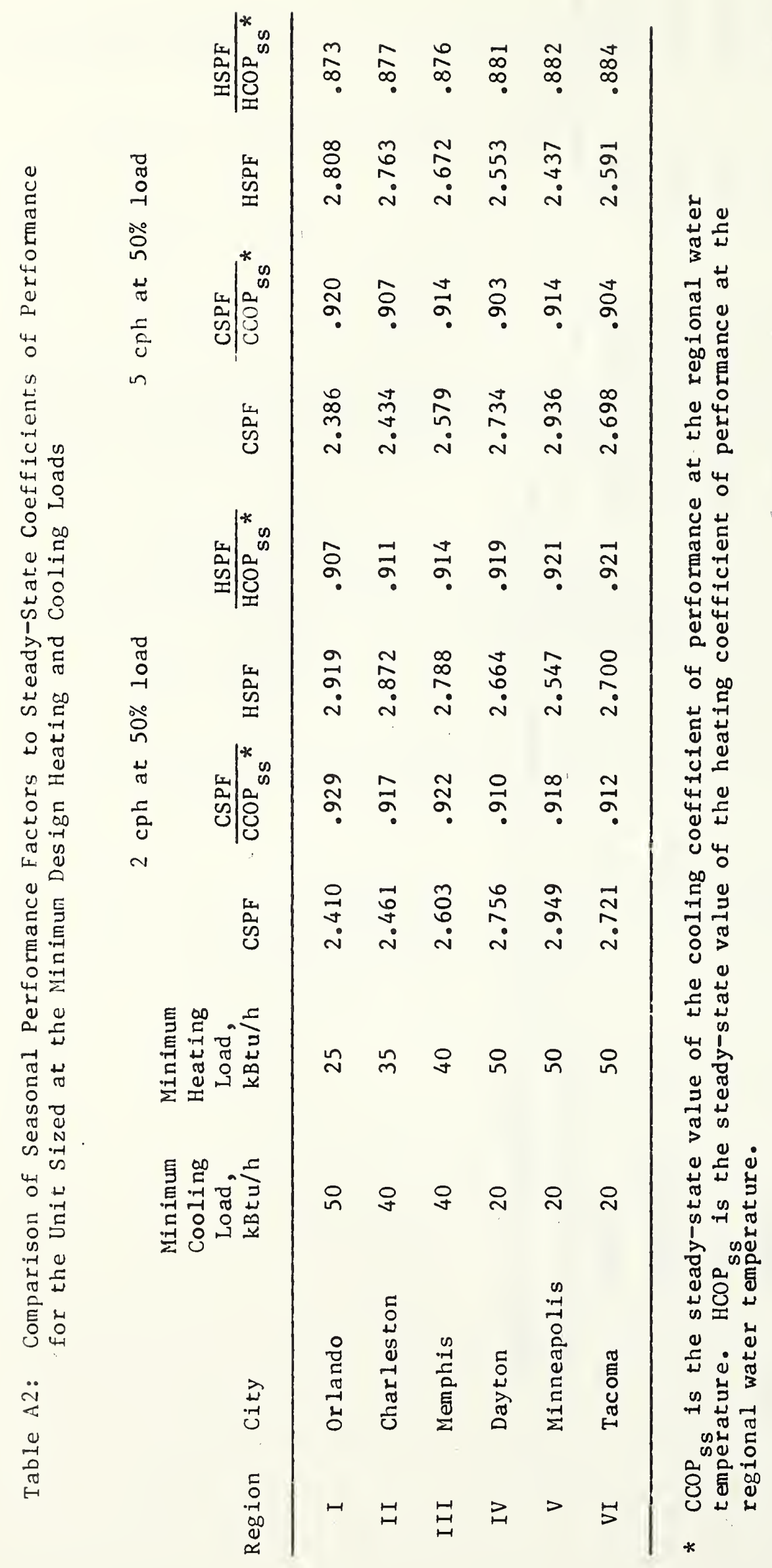




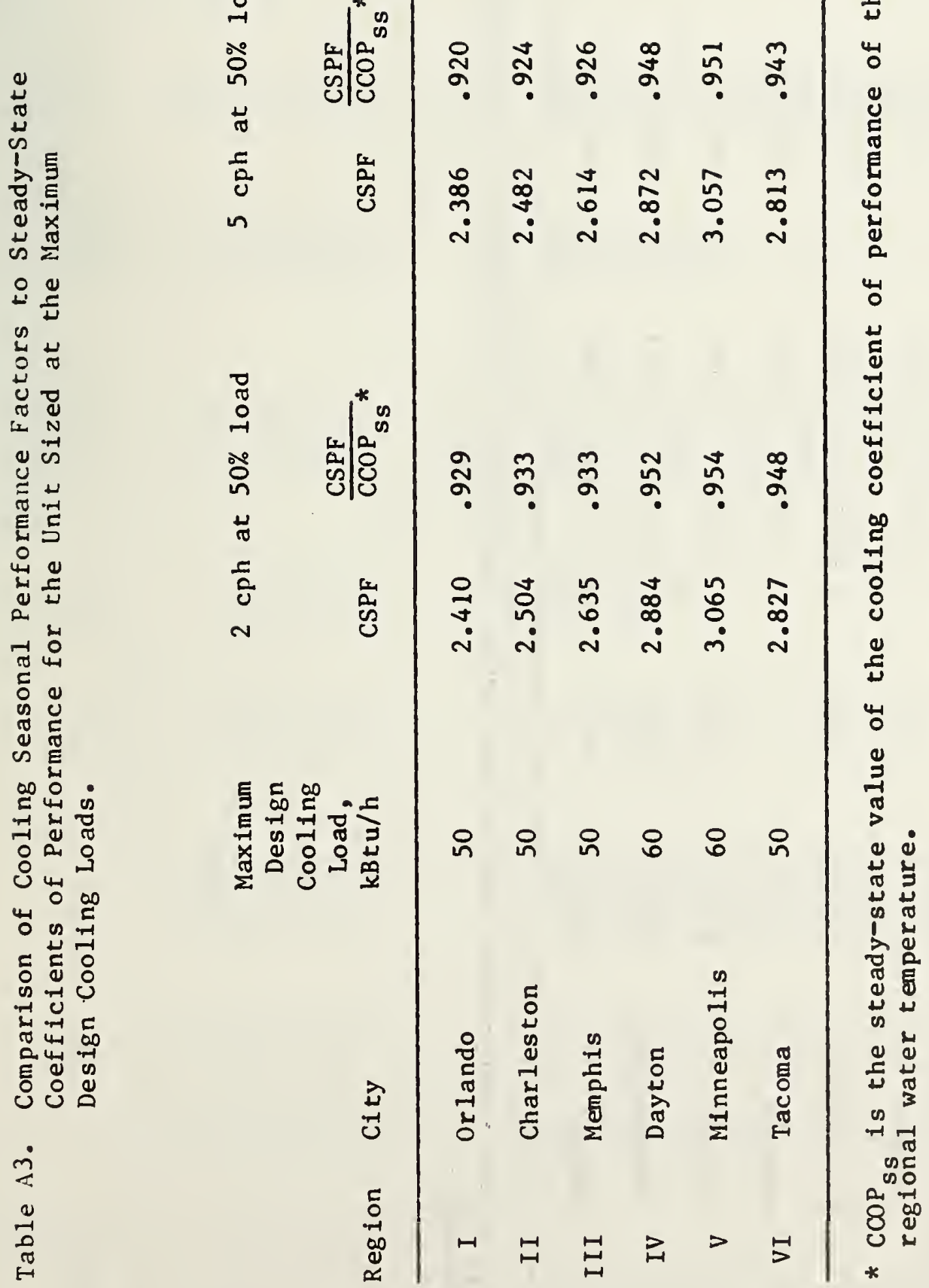




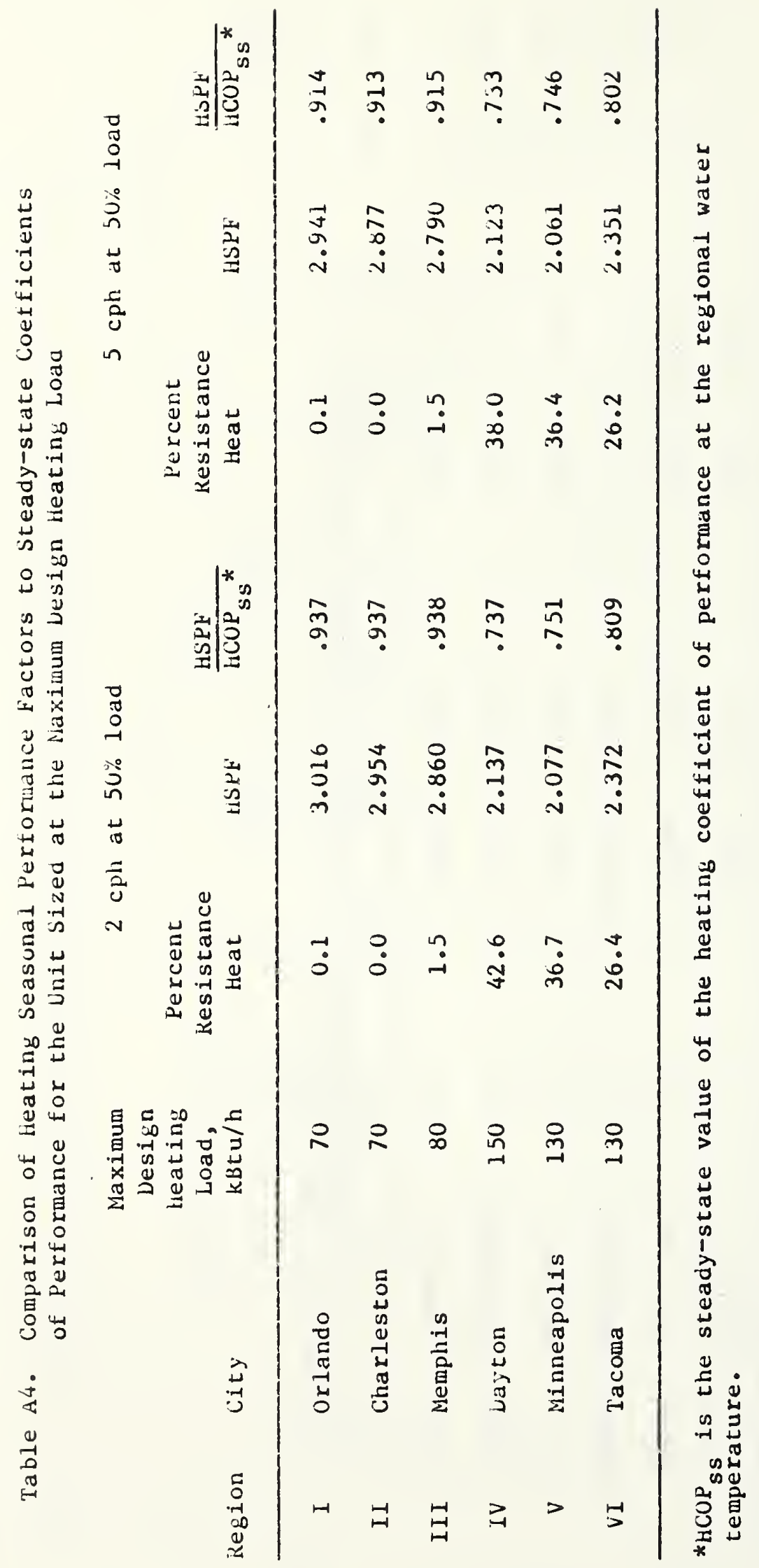




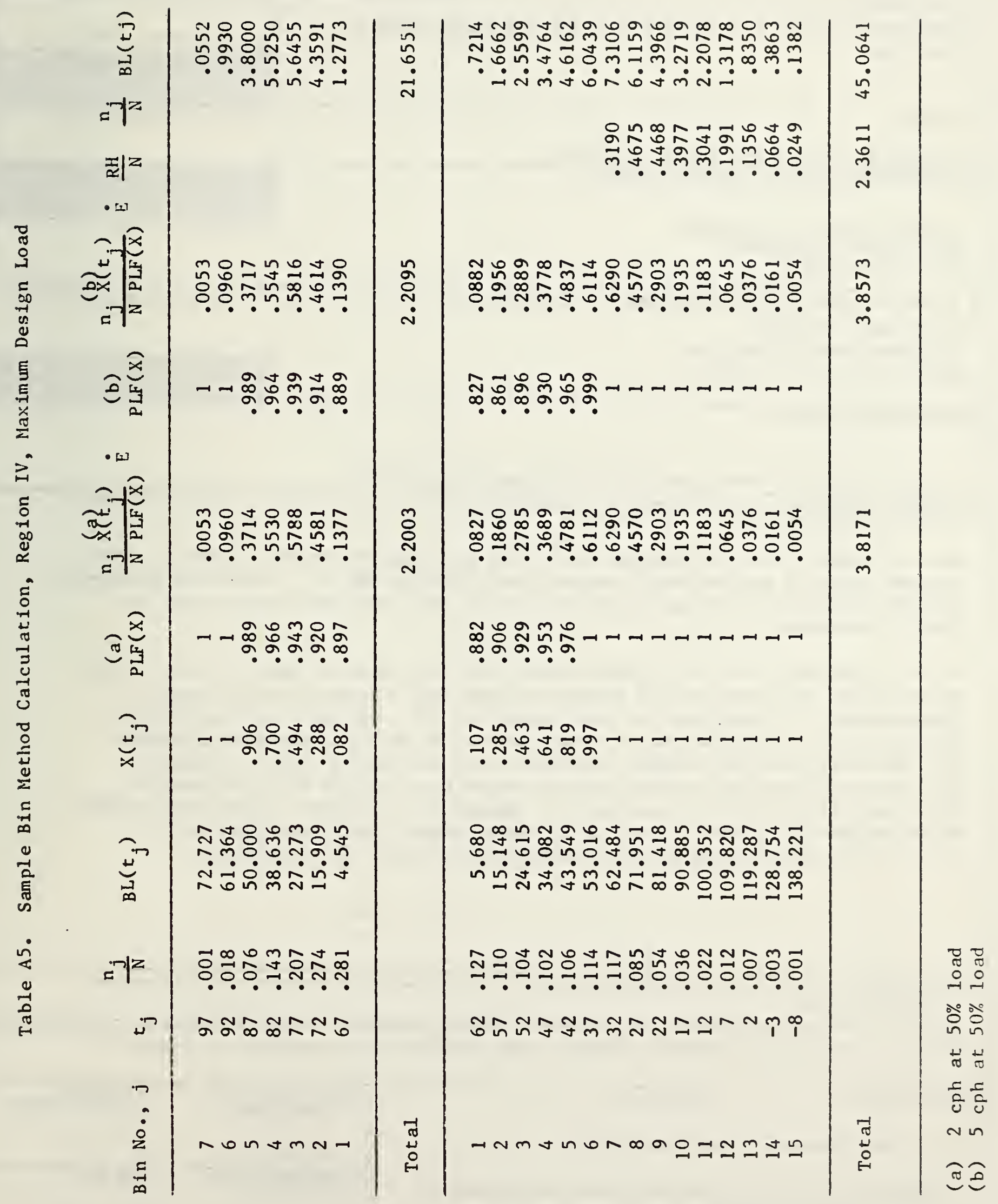




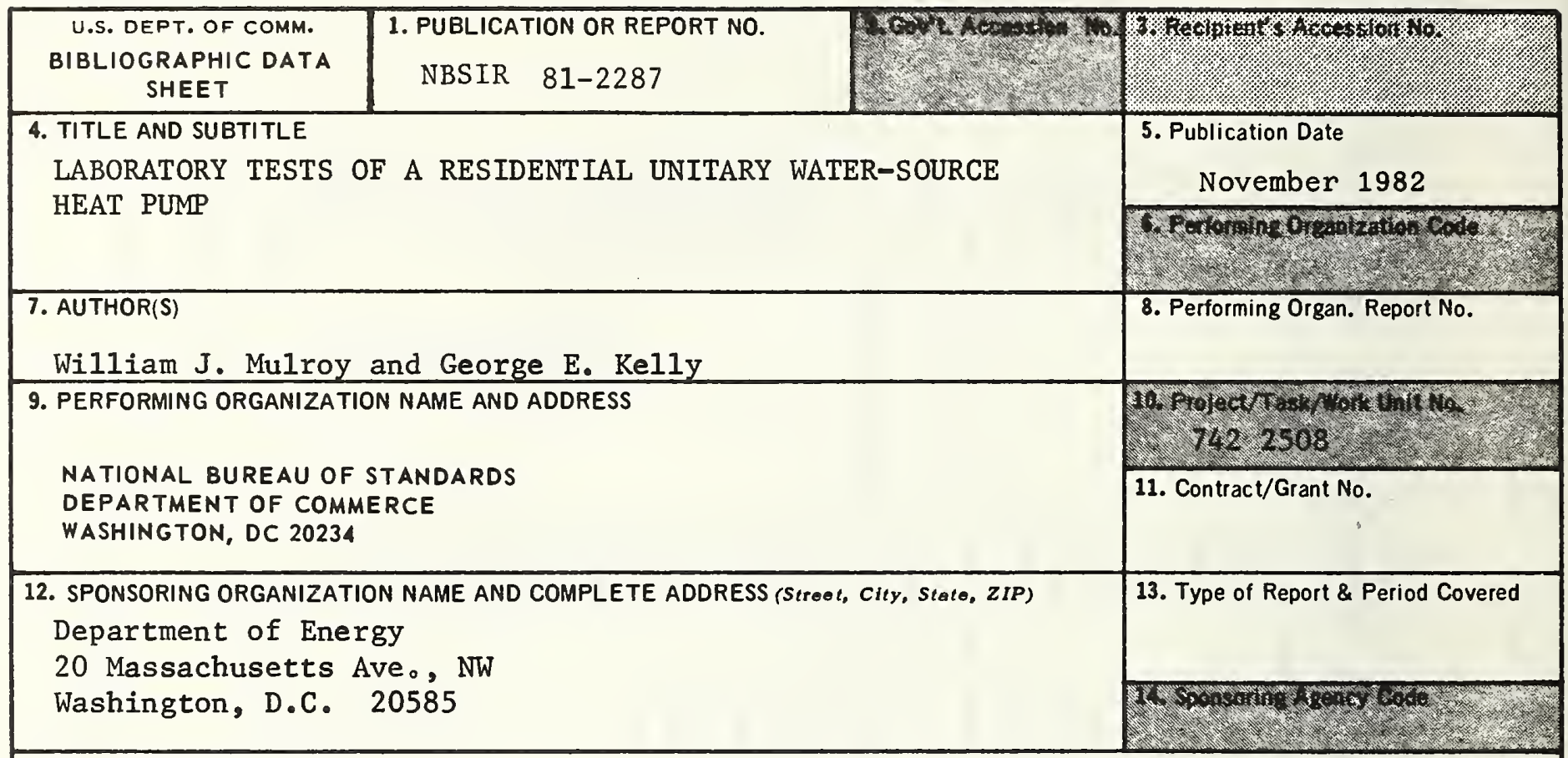

15. SUPPLEMENTARY NOTES

Document describes a computer program; SF-185, FIPS Software Summary, is attached.

16. ABSTRACT (A 200-word or less factual summary of most significant information. If document includes a significant blbliography or literature survey, mention it here.)

The performance of a residential heat pump was measured in the laboratory over a broad range of source water temperatures $\left(40^{\circ} \mathrm{F}\right.$ to $\left.90^{\circ} \mathrm{F}\right)$. Tests were performed in both heating and cooling operational modes and for both steady-state and cyclic operation.

For both heating and cooling operations, the unit capacity and COP were found to be linear functions of the average of the unit source and outlet water temperatures. In heating, the unit capacity, COP, and part load performance increased with increasing water temperature. In cooling, the unit capacity, $\mathrm{COP}$, and part load performance decreased with increasing water temperature。 The measured degradation coefficients ranged from 0.09 to 0.21 for heating and from 0.10 to 0.18 for cooling. An appendix is included in which the effect of the degradation coefficient and of supplemental resistance heat on the unit heating and cooling seasonal performance factors is calculated.

17. KEY WORDS (six to twelve entries; alphabetical order; capitalize only the first letter of the first key word unleas a proper name; separated by semicolons)

Central heating equipment; cooling; heat pumps; heating; heating seasonal performance; heating seasonal performance factor; test method; water source heat pumps

18. AVAILABILITY X. Unlimited

For Official Distribution. Do Hot Release to NTIS

Order From Sup. of Doc., U.S. Government Printing Office, Washington, DC 20402, SD Stock No. SNODO3-003-

X] Order From National Technical Information Service (NTIS), Springfield, VA. 22161

\begin{tabular}{|l|c|}
\hline $\begin{array}{l}\text { 19. SECURITY CLASS } \\
\text { (THIS REPORT) }\end{array}$ & $\begin{array}{c}\text { 21. NO. OF } \\
\text { PRINTED PAGES } \\
\text { UNCLASSIFIED }\end{array}$ \\
\hline $\begin{array}{l}\text { 20. SECURITY CLASS } \\
\text { (THIS PAGE) }\end{array}$ & 51 \\
UNCLASSIFIED & 22. Price \\
\hline
\end{tabular}



